\title{
The pollination ecology of Persoonia (Proteaceae) in eastern Australia
}

\author{
Peter Bernhardt and Peter H. Weston
}

\begin{abstract}
Bernhardt, Peter \& Weston, Peter H. (Dept. of Biology, St. Louis University, St. Louis, Missouri, U.S.A. 63103; National Herbarium of New South Wales, Royal Botanic Gardens, Sydney, NSW, Australia 2000) 1996. The pollination ecology of Persoonia (Proteaceae) in eastern Australia. Telopea 6(4): 775-804. Twenty Persoonia spp. and two interspecific hybrids ( $P$. acerosa $\times$ P. levis, P. microphylla $\times$ P. mollis) native to eastern Australia were examined. Although these radially symmetrical flowers appear to have a tubular perianth each tepal is hinged at its base and opens outwardly when depressed by an insect at least $6 \mathrm{~mm}$ long. These species show an aestival-autumnal flowering peak and four, differing, floral scents were recognised. Persoonia pinifolia and P. subvelutina produce nectar that is sucrose dominant. Twenty two insect taxa were collected on the flowers but field observations and the analyses of pollen loads carried by insects suggested that Persoonia is pollinated primarily by bees. Specifically, the most consistent pollen vectors were native Leioproctus species (Colletidae; subgenus Cladocerapis) and Exoneura species (Anthophoridae). Pollen load analyses showed that both Exoneura and Leioproctus spp. also foraged on the flowers of Myrtaceae and other co-blooming taxa. The deposition of Persoonia pollen on these bees was both dorsal and ventral as their contact with anthers was both active and passive. Female bees in subgenus Cladocerapis usually carried heavier loads of pollen than males, which appeared to forage for nectar exclusively.

Leioproctus (Cladocerapis) spp. observed on $P$. glaucescens, $P$. lanceolata and $P$. mollis showed stereotyped modes of pollen collection confirming observations first made by Rodd as cited by Rayment (1950). At two sites, $28 \%$ of the bees collected carried the pollen of more than one Persoonia species. The high frequency of first generation hybrids between Persoonia species is explained, in part, by a combination of overlapping distributions, flowering periods and pollinators.
\end{abstract}

\section{Introduction}

Most of the literature on the pollination ecology of Australasian Proteaceae has been produced within the last twenty years. Consequently, when the monumental review of the family by Johnson and Briggs (1975) is re-read today, the section entitled 'Inflorescences and Pollination', seems rather speculative.

Johnson and Briggs' records of vertebrate pollinators came primarily from anecdotal references or from the colour photos of wildlife photographers. Papers referring to the foraging of Australian bees on the flowers of the Proteaceae were still scattered through the entomological literature and would not be compiled and cross-referenced until Armstrong (1979).

Today, the study of the floral biology of Australasian Proteaceae has become important to the science of pollination ecology for two reasons. First, many taxa are such dependable and copious producers of nectar that it is relatively easy to quantify the calorific content of individual flowers and/or whole inflorescences (Paton 1985). Since much of the nectar produced by these taxa is consumed by passerine birds and loriid parrots, bird/flower interactions provide one of the most visible model systems to test theories of optimal foraging theory and resource allocation (Pyke \& Waser 1981; Pyke 1982).

The movement of vertebrates through the habitat is relatively easier to see and track compared to most insects. No wonder recent, comparative studies of pollination 
systems within the Proteaceae have favoured bird or mammal-pollinated taxa. For example, Collins and Rebelo (1987) add new information on functional morphology and floral behaviour of Proteaceae in Australia and southern Africa. However, they concentrate on vertebrate-pollinated genera and remark that information on entomophilous systems remains 'rudimentary'.

Second, Sussman and Raven (1978) offered a novel interpretation of the wiry protostigmas found in most genera in the Proteaceae. They suggested that there had been an early association between angiosperm flowers and small, wingless mammals. The tough, curved style served both as a pollen presenter and as a 'rung' for a climbing mammal. Arboreal rodents and marsupials in Australia do feed on the nectar and pollen of native Proteaceae (Turner 1982). However, their role as agents of cross-pollination remains controversial since Hopper and Burbidge (1982) accuse these mammals of consuming or grooming away pollen deposits in fur and whiskers before it is transferred to the stigma of a second genotype. There has been additional evidence that large bats (Megachiroptera) may also pollinate some Banksia spp. (Law 1994) as first predicted by Johnson and Briggs (1975). However, research directed exclusively towards vertebrate pollination of Australasian Proteaceae will always result in a biased and incomplete interpretation of floral evolution of this family.

If pollination by vertebrates is an ancestral feature of the Proteaceae why do so many rainforest relicts (e.g. Placospermum, Eidothea, Carnarvonia, Sphalmium, Neorites, Cardwellia, Buckinghamia, Opisthiolepis, Floydia, Musgravea) lack the full suite of reproductive characters associated with vertebrate-pollination? In fact, pollination by birds or wingless mammals has been recorded far more frequently in the Proteaceae of sclerophyllous woodlands and shrublands (Hopper and Burbidge 1982, 1986; Paton 1986; Turner 1982; Collins and Rebelo 1987). Similarly, why do most basal lineages in the Proteaceae, such as the Persoonioideae, Bellendenoideae, Carnarvonioideae, Sphalmioideae, Eidotheoideae and the tribe Conospermeae (Proteoideae) lack the suite of characters associated with vertebrate pollination?

Based on patterns of character distribution in the Proteaceae, Johnson and Briggs (1975) inferred that the family was primitively entomophilous and restricted to closed, mesothermic forests. Evolutionary shifts to vertebrate pollination and to xeric habitats was inferred to be a secondary and often recurrent process. Primitive occurrence in rainforests has been supported, in part, by the fossil evidence (Truswell 1990).

The genus Persoonia would appear to be the most logical choice to help close the information gap on the role of insects in floral evolution within the Proteaceae. Comparatively few Persoonia species occur in rainforests; most are shrubs or small trees of sclerophyll woodlands and shrublands. Consequently, many Persoonia species form far denser and more readily accessible populations (see Weston 1991, 1994; Weston and Johnson 1991) than those rainforest relicts listed above.

Of greater importance, Persoonia belongs to the Persoonioideae, the only subfamily that completely lacks proteoid roots and thus is likely to be one of the most basal lineages in the family. The Persoonioideae also shows no evidence of protostigma development considered synapomorphic in at least three different lineages that include most of the genera in the family. Persoonia may then provide a model system for understanding evolutionary trends in the functional morphology of the flowers of Proteaceae.

Bees in the long-tongue families Anthophoridae (Allodapula, Amegilla, Exoneura), Apidae (Apis, Trigona) and Megachilidae (Chalicodoma, Megachile) have been reported to collect nectar and/or pollen on Persoonia species (Armstrong 1979). Pollination mechanisms in Persoonia were first addressed by two amateur entomologists in a little known paper (Rayment 1950). Rayment described three new species of shorttongue bees in the genus Cladocerapis (now Leioproctus subgenus Cladocerapis) including 
correspondence from Norman Rodd concerning the unusual mode of pollen foraging by these bees on Persoonia mollis. Rodd deposited a voucher specimen (NSW 21325) from one of the shrubs visited by Leioproctus bees. It has since been identified as P. mollis subsp. ledifolia as cited by Krauss \& Johnson (1991).

Rodd described how these members of the Colletidae landed on the recurved tepals, and then pushed both their front legs down the longitudinal slit on each side of an anther, scooping out pollen. The pollen retained in the claws of each front leg was then transferred to the collection hairs on the back legs. Rayment (1950) also included a detailed, pen and ink illustration showing how the smooth clypeus of the bee slides down against the central style while the bee inserts its tongue between the tepal and the ovary stalk to probe for nectar secreted by four receptacular glands. Rodd excavated the bees' burrows for Rayment and noted that the pollen loaves or 'puddings' made by Cladocerapis bees smelled strongly of Persoonia flowers.

Unfortunately, many of Rayment's publications have since been discredited by contemporary entomologists, so his field observations and microscopy must be repeated and rechecked. However, while other entomologists have studied bees that forage on Persoonia species (Maynard 1992, 1994, 1995), they have never determined which bee species are true pollinators, nectar thieves or pollen scavengers. In fact, Rayment (1950) provides the only written record and illustration of Persoonia pollen removed from the body of a few bees belonging to the same genus.

Maynard $(1992,1994)$ suggested that two subgenera in Leioproctus (Cladocerapis and Filiglossa), are oligolectic (sensu Michener 1979) on Persoonia. However, Maynard (1992) also reported that some Leioproctus spp. in subgenus Cladocerapis were also captured on flowers of Leptospermum sp., Lomatia silaifolia and Claoxylon australis. This suggests that not all species in subgenus Cladocerapis forage exclusively on Persoonia.

Establishing which animals are responsible for the majority of successful pollinations in Persoonia is important for two reasons. Firstly, artificial pollinations and allozyme electrophoresis by Krauss (1994a, 1994b) have shown that the Persoonia mollis complex is dominated by outcrossing genotypes. Self-pollination rarely results in successful seedset. Small sample sizes suggest that the successful pollination of one genotype by a second was usually no greater than the distance between immediate neighbours (Krauss 1994a, 1994b). Therefore, it is possible that pollen dispersal within the P. mollis complex is clumped or leptokurtic (sensu Richards 1986).

Second, in eastern Australia Persoonia species show an unusually high level of F1 hybrids (Weston 1991; Table 1). Therefore, fieldwork on the pollination ecology of sympatric species also helps assess degrees of weakness in different, prezygotic barriers to interspecific isolation.

\section{Materials and methods}

\section{Study sites}

Wild populations of 20 species of Persoonia (Table 2) and two hybrid plants were studied at 17 different sites. Detailed descriptions of those localities are listed in the appendix.

\section{Recording data on reproductive features}

To record the floral phenology of each taxon in this study, the month of collection of each flowering specimen held at NSW was recorded. Multiple collections of the same taxon made by the same collector on the same day were recorded as a single datum. The resulting data were tabulated as the frequency of flowering records for each month for each taxon. 
Table 1. Pair-wise matrix showing inferred natural hybridisation and intergradation between all Persoonia species in New South Wales and Victoria; $s$ indicates that two species are sympatric over part of their distributions and that no putative hybrids have been collected; $h$ indicates that two species are sympatric over part of their distributions and that putative hybrids have been collected; $i$ indicates that two species have parapatric distributions and intergrade with one another.

\begin{tabular}{|c|c|c|c|c|c|c|c|c|c|c|c|c|c|c|c|c|}
\hline & 1 & 2 & 3 & 4 & 5 & 6 & 7 & 8 & 9 & 10 & 11 & 12 & 13 & 14 & 15 & 16 \\
\hline 1 acerosa & $x$ & & & & & & & & & & & & & & & \\
\hline 2 acuminata & & $x$ & & & & & & & & & & & & & & \\
\hline 3 adenantha & & & $x$ & & & & & & & & & & & & & \\
\hline 4 arborea & & & & $x$ & & & & & & & & & & & & \\
\hline 5 asperula & & & & & $x$ & & & & & & & & & & & \\
\hline 6 bargoensis & & & & & & $x$ & & & & & & & & & & \\
\hline 7 brevifolia & & & & & & & $x$ & & & & & & & & & \\
\hline 8 chamaepeuce & & $\mathrm{s}$ & & & $h$ & & & $x$ & & & & & & & & \\
\hline 9 chamaepitys & 5 & & & & & & & & $x$ & & & & & & & \\
\hline 10 confertiflora & & & & & $s$ & & & $\mathrm{~h}$ & & $x$ & & & & & & \\
\hline 11 conjuncta & & & & & & & & & & & $x$ & & & & & \\
\hline 12 cornifolia & & & & & & & & 5 & & & & $x$ & & & & \\
\hline 13 curvifolia & & & & & & & & & & & & & $x$ & & & \\
\hline 14 cuspidifera & & & & & & & & & & & & & i & $x$ & & \\
\hline 15 daphnoides & & & & & & & & & & & & $s$ & I & & $x$ & \\
\hline 16 fastigiata & & & & & & & & & & & & $h$ & & & & $x$ \\
\hline 17 glaucescens & $\mathrm{s}$ & & & & & & & & & & & & & & & \\
\hline 18 hirsuta & $\mathrm{s}$ & & & & & $\mathrm{s}$ & & & & & & & & & & \\
\hline \multicolumn{17}{|l|}{19 isophylla } \\
\hline 20 juniperina & & & & & & & & & & $\mathrm{s}$ & & & & & & . \\
\hline \multicolumn{17}{|l|}{21 katerae } \\
\hline 22 lanceolata & $\mathrm{s}$ & & & & & & & & & & & & & & & \\
\hline 23 laurina & $\mathrm{s}$ & 5 & & & $s$ & s & & $s$ & 5 & & & & & & & \\
\hline \multicolumn{17}{|l|}{24 laxa } \\
\hline 25 levis & $h$ & & & & & & & & $\mathrm{~s}$ & $s$ & & & & & & \\
\hline 26 linearis & $h$ & & & & 5 & $s$ & & & s & s & $h$ & & $h$ & & & \\
\hline \multicolumn{17}{|l|}{27 marginata } \\
\hline 28 media & & $s$ & & & & & & & & & $i$ & & & & & \\
\hline \multicolumn{17}{|l|}{29 microphylla } \\
\hline 30 mollis & $s$ & & & & & & & & $\mathrm{~s}$ & & & & & & & \\
\hline 31 myrtilloides & h & & & & & & & & s & & & & & & & \\
\hline \multicolumn{17}{|l|}{32 nutans } \\
\hline 33 oblongata & & & & & & & & & $s$ & & & & & & & \\
\hline 34 oleoides & & & & & & & & & & & & $h$ & & & s & \\
\hline \multicolumn{17}{|l|}{35 oxycoccoides } \\
\hline \multicolumn{17}{|l|}{36 pinifolia } \\
\hline 37 procumbens & & & & & & & & & & & & $s$ & & & & $s$ \\
\hline 38 recedens & 5 & & & & & & & & s & & & & & & & \\
\hline 39 rigida & & & & & & & & s & & s & & & & & & \\
\hline \multicolumn{17}{|l|}{40 rufa } \\
\hline 41 sericea & & & & & & & & s & & & & $h$ & $h$ & h & 5 & \\
\hline 42 silvatica & & & & & s & & $\mathrm{s}$ & 5 & & & & & & & & \\
\hline 43 stradbrokensis & & & $\mathrm{i}$ & & & & & & & & $i$ & & & & & \\
\hline 44 subvelutina & & & & & & & & $s$ & & $\mathrm{~s}$ & & & & & & \\
\hline 45 tenuifolia & & & & & & & & & & & & & & & $\mathrm{s}$ & \\
\hline \multicolumn{17}{|l|}{46 terminalis } \\
\hline 47 virgata & & & 5 & & & & & & & & & & & & & \\
\hline 48 volcanica & & & & & & & & & & & & & & & & \\
\hline
\end{tabular}




\begin{tabular}{|c|c|c|c|c|c|c|c|c|c|c|c|c|c|c|c|c|}
\hline & 17 & 18 & 19 & 20 & 21 & 22 & 23 & 24 & 25 & 26 & 27 & 28 & 29 & 30 & 31 & 32 \\
\hline 17 glaucescens & $\mathrm{x}$ & & & & & & & & & & & & & & & \\
\hline 18 hirsuta & $s$ & $x$ & & & & & & & & & & & & & & \\
\hline 19 isophylla & & $s$ & $x$ & & & & & & & & & & & & & \\
\hline 20 juniperina & & & & $x$ & & & & & & & & & & & & \\
\hline 21 katerae & & & & & $x$ & & & & & & & & & & & \\
\hline 22 lanceolata & s & $s$ & $s$ & & $\mathrm{~h}$ & $x$ & & & & & & & & & & \\
\hline 23 laurina & 5 & $\mathrm{~s}$ & $s$ & & & $s$ & $x$ & & & & & & & & & \\
\hline 24 laxa & & $s$ & 5 & & & 5 & $s$ & $x$ & & & & & & & & \\
\hline 25 levis & $s$ & 5 & $s$ & 5 & 5 & $\mathrm{~h}$ & 5 & $\mathrm{~h}$ & $x$ & & & & & & & \\
\hline 26 linearis & $s$ & $s$ & $s$ & 5 & & $\mathrm{~h}$ & $s$ & $s$ & $\mathrm{~h}$ & $x$ & & & & & & \\
\hline 27 marginata & & & & & & & & & & $\mathrm{S}$ & $x$ & & & & & \\
\hline 28 media & & & & & & & & & & h & & $x$ & & & & \\
\hline 29 microphylla & & & & & & & $s$ & . & & 5 & & & $x$ & & & \\
\hline 30 mollis & $s$ & $s$ & & & & $s$ & $s$ & & $h$ & $h$ & & & $h$ & $x$ & & \\
\hline 31 myrtilloides & & & & & & & $s$ & & $h$ & $h$ & & & & $s$ & $x$ & \\
\hline 32 nutans & & $s$ & & & & & $s$ & & $s$ & 5 & & & & & & $x$ \\
\hline 33 oblongata & & $s$ & & & & & 5 & & $s$ & 5 & & & & $s$ & & \\
\hline 34 oleoides & & & & & & & & & & $h$ & & $\mathrm{~h}$ & & & & \\
\hline 35 oxycoccoides & & & & & & & 5 & & $h$ & 5 & & & & $s$ & & \\
\hline 36 pinifolia & & $s$ & & & & $s$ & $s$ & 5 & $s$ & $\mathrm{~h}$ & & & & $s$ & & \\
\hline \multicolumn{17}{|l|}{37 procumbens } \\
\hline 38 recedens & & & & & & & $s$ & & $s$ & & & & & & $h$ & \\
\hline 39 rigida & & & & $s$ & & & & & & 5 & 5 & & & & & \\
\hline \multicolumn{17}{|l|}{40 rufa } \\
\hline 41 sericea & & & & & & & & & & $h$ & & & & & & \\
\hline 42 silvatica & & & & & & & & & $s$ & $s$ & & & & & & \\
\hline 43 stradbrokensis & & & & & & h & & & $h$ & & & & & & & \\
\hline \multicolumn{17}{|l|}{44 subvelutina } \\
\hline \multicolumn{17}{|l|}{45 tenuifolia } \\
\hline \multicolumn{17}{|l|}{46 terminalis } \\
\hline 47 virgata & & & & & $s$ & $h$ & & & & & & & & & & \\
\hline 48 volcanica & & & & & & & & & & & & & & & & \\
\hline
\end{tabular}

\begin{tabular}{|c|c|c|c|c|c|c|c|c|c|c|c|c|c|c|c|c|}
\hline & 33 & 34 & 35 & 36 & 37 & 38 & 39 & 40 & 41 & 42 & 43 & 44 & 45 & 46 & 47 & 48 \\
\hline 33 oblongata & $x$ & & & & & & & & & & & & & & & \\
\hline 34 oleoides & & $x$ & & & & & & & & & & & & & & \\
\hline 35 oxycoccoides & & & $x$ & & & & & & & & & & & & & \\
\hline 36 pinifolia & 5 & & & $x$ & & & & & & & & & & & & \\
\hline 37 procumbens & & $s$ & & & $x$ & & & & & & & & & & & \\
\hline 38 recedens & & & & & & $x$ & & & & & & & & & & \\
\hline 39 rigida & & & & & & & $x$ & & & & & & & & & \\
\hline 40 rufa & & & & & & & & $x$ & & & & & & & & \\
\hline 41 sericea & & & & & & & & & $x$ & & & & & & & \\
\hline 42 silvatica & & & & & & & & & & $x$ & & & & & & \\
\hline 43 stradbrokensis & & & & & & & & & $\mathrm{h}$ & & $x$ & & & & & \\
\hline 44 subvelutina & & & & & & & & & & & & $x$ & & & & \\
\hline 45 tenuifolia & & & & & & & & & $\mathrm{h}$ & & $h$ & & $x$ & & & \\
\hline 46 terminalis & & & & & & & & & $\mathrm{h}$ & & & & $s$ & $x$ & & \\
\hline 47 virgata & & & & & & & & & s & & $\mathrm{h}$ & & $s$ & & $x$ & \\
\hline 48 volcanica & & & & & & & & & & & & & & & & $x$ \\
\hline
\end{tabular}


Table 2. Flowering phenology of Persoonia species from which bees were collected for this study; each entry is the number of flowering specimens collected during a calendar month, held by NSW; sets of multiple collections made at the same site on the same day were each treated as a single record.

\begin{tabular}{|c|c|c|c|c|c|c|c|c|c|c|c|c|}
\hline & Oct & Nov & Dec & Jan & Feb & Mar & Apr & May & Jun & Jul & Aug & Sep \\
\hline acerosa & - & - & 1 & 9 & 6 & 5 & 5 & 2 & - & - & - & - \\
\hline arborea & - & - & - & - & 2 & - & - & - & - & - & - & - \\
\hline asperula & - & - & - & 6 & - & 2 & - & - & 1 & - & - & - \\
\hline chamaepeuce & 1 & - & 6 & 25 & 15 & 4 & - & 1 & - & - & 1 & - \\
\hline chamaepitys & - & 6 & 11 & 2 & - & - & - & - & - & - & - & - \\
\hline glaucescens & - & - & - & 2 & 4 & 1 & - & 1 & - & - & - & - \\
\hline isophylla & - & - & 1 & 1 & 2 & 3 & 3 & - & 1 & - & - & - \\
\hline lanceolata & 2 & - & 2 & 4 & 8 & 7 & 6 & 5 & 3 & - & 2 & - \\
\hline laurina subsp. laurina & 1 & 5 & 9 & 3 & 1 & 1 & - & - & - & - & - & - \\
\hline levis & 2 & 5 & 8 & 2 & 3 & 3 & 1 & 2 & - & - & - & 2 \\
\hline microphylla & - & - & 4 & 1 & 1 & 1 & - & - & - & - & - & - \\
\hline mollis & 2 & 1 & 8 & 18 & 21 & 21 & 12 & 9 & 4 & 5 & 4 & 3 \\
\hline $\begin{array}{l}\text { myrtilloides } \\
\text { subsp. myrtilloides }\end{array}$ & - & - & 10 & 9 & 4 & 2 & 1 & 1 & - & - & - & - \\
\hline nutans & - & 1 & 7 & 4 & - & 1 & 1 & - & 2 & 3 & - & 1 \\
\hline oblongata & - & - & - & 2 & 4 & 3 & 2 & 1 & 1 & - & - & - \\
\hline oxycoccoides & - & - & 3 & 5 & 1 & 1 & 1 & - & 1 & - & - & - \\
\hline pinifolia & - & - & 3 & 8 & 6 & 3 & 1 & 1 & 2 & 2 & - & - \\
\hline silvatica & 1 & 1 & 4 & 11 & 1 & - & - & - & - & - & - & - \\
\hline subvelutina & - & - & - & 3 & 7 & 1 & - & - & - & - & - & - \\
\hline virgata & 1 & 1 & 3 & 11 & 3 & 3 & 1 & 4 & 1 & - & 1 & - \\
\hline
\end{tabular}

For each taxon in this study, one tepal (plus its attached stamen) was removed from most, or all, of the flowering specimens held at NSW. Care was taken not to sample from multiple duplicates of a single collection. The tepal/stamens were rehydrated by soaking in distilled water overnight, which effectively restored their fresh, threedimensional form. For each tepal/stamen, the length of the floral tube was measured under 10x magnification, using an eyepiece micrometer fitted to a stereo dissecting microscope. The length of the floral tube was defined as the linear distance between the base of the staminal filament (where it is adnate to its tepal) and the point at which the stamen becomes free from its tepal (at, or slightly above or below, the base of the anther). In most species, this is the point at which the tepal starts to recurve, thus losing coherence with the adjacent tepals. Measurements were scored by taxon and summary statistics (sample size, mean, range, standard deviation) calculated.

Sampling floral odour follows Bernhardt (1995) and Buchmann et al. (1978). Fresh flowers were placed in clean, glass vials and sealed for 15 minutes, 30 minutes, 45 minutes, one hour and two hours. The vials were placed in a warm, sunny location, then reopened and smelled. To determine possible sites of scent glands (osmophoric activity) whole flowers of seven species were submerged in a $1 \%$ solution of Neutral Red for two to 24 hours, then washed in distilled water for two hours. Living flowers of $P$. cornifolia (living collections number 973375) and P. katerae (living collections number 877128) used for scent tests came from shrubs grown at the Mount Annan Botanic Garden and the Royal Botanic Gardens, Sydney, repectively. 
Nectar samples were collected by bagging individual flowers or whole inflorescences in situ overnight. The following morning each flower was probed with a ten lambda microcapillary tube. Since no flower produced as much as 10 microlitres of nectar, samples represent combined measurements from several flowers on the same shrub or several shrubs of the same species. Once ten microlitres was obtained the contents of the tube was deposited on Whatman's Filter Paper No.1. The contents were air dried, labelled and stored in a paper envelope and mailed to C.E. Freeman (Dept. of Biological Sciences, University of Texas, El Paso) to identify component sugars and record their relative proportions.

\section{Analyses of foraging insects}

Observation of prospective pollinators and analyses of the pollen they carried followed Bernhardt (1984, 1995). The behaviour of insects on Persoonia flowers was recorded from 9 am until 4:30 pm. Insects were collected only if they were observed probing for nectar or actively collecting pollen. Insects were killed in jars containing fumes of ethyl acetate. Insects caught on different Persoonia species were always killed in separate jars. Jars were cleaned after each collecting trip to avoid contamination upon reuse. To analyse pollen carried by insects, each insect was placed on a clean glass slide and 'bathed' in a couple of drops of $100 \%$ ethanol. When the ethanol evaporated, the residue remaining on the slide was mounted in two or three drops of Calberla's fluid (Ogden et al. 1974). Identification of pollen was made under light microscopy. However, since more than one insect was killed in the same jar, some pollen contamination of insect bodies was possible. Therefore, a pollen taxon was not recorded as present on an insect unless more than 25 individual monads or 25 individual polyads (e.g. of Epacridaceae) could be counted under each cover slip (see Bernhardt 1984, 1995).

Light microscopy showed that, as under SEM (Feuer 1986), pollen grains of different Persoonia species may be identified using a combination of characters including the physical size of the grain, the length and angle of pollen lobes, the inflation of pore opercula, density of tectum scabs and the frequency of tetraporate grains and/or irregular lobes. While these characters intergrade broadly between many species it is possible to discriminate between the pollen of up to three, co-blooming, sympatric Persoonia species carried on the same insect and washed onto the same slide.

The length of each insect specimen was measured from its labrum to the apex of its abdomen. The insect was pinned, labelled to cross-reference with its pollen slide and sent to Dr K. Walker (National Museum of Victoria, Abbotsford) for identification.

\section{Results}

\section{Floral phenology}

Herbarium records indicated that there are likely to be some populations within the genus Persoonia in bloom each month of the year within New South Wales. However, flowering is greatest from December through April (Table 2). Interspecific overlap of flowering periods was found for each Persoonia species.

The flowering of a few species, such as $P$. laurina and $P$. chamaepitys was found to peak between late spring and early summer. Collections were few but the flowering of montane and subalpine $P$. subvelutina and $P$. arborea appeared confined to late summer. Flowering on a stem is acropetal to subacropetal in all species studied. 


\section{Floral presentation}

Upon expansion of the perianth, the flowers of most Persoonia species are held suberect (45 degrees) to horizontal in relation to the axis of the branch supporting the inflorescence. The flowers of P. microphylla, P. myrtilloides, $P$. nutans and $P$. oblongata nod on dangling pedicels less than 180 degrees to the axis.

The presentation of the tepals varies within the genus Persoonia. Some species produce a zygomorphic perianth but most are actinomorphic (Weston 1994). All eastern Australian species in this study have actinomorphic perianths with tepals forming a radially symmetrical tube or vase around the stalked ovary. The base of each tepal is a short, thin, flexible hinge (Fig. 1). In most species the tepals constrict to clasp the gynoecium. Since the anthers are fused to the tepals they form a secondary tube around the protruding style (Fig. 1). Therefore, less than a third of the style is usually visible in whole living flowers, as it is covered by the tepals and occluded further by the angled lower halves of the anthers (Fig. 1). In $P$. arborea and $P$. chamaepitys the tepals are not constricted so both the entire style and top of the ovary are visible to the viewer over the floral lifespan (Table 3).

Tepal length varies between species, producing tubes of different lengths and shapes (Fig. 2; Table 3). In P. arborea, for example, the tube is long, may curve and tends to constrict at its base, becoming trumpet-like or funnel-shaped (Fig. 2). In contrast, the tube of $P$. pinifolia expands at its base forming a bulbous pouch (Fig. 1). In P. levis the tube is so reduced it grades abruptly into a pot or pouch (Fig. 2). Persoonia arborea, $P$. chamaepitys, $P$. silvatica and $P$. subvelutina were the only species sampled that produce floral tubes greater than $4 \mathrm{~mm}$ long (Table 3). There was no correlation between tube length, topography or altitude.

Table 3. Floral tube length $(\mathrm{mm})$ for each species of Persoonia from which bees were collected for this study, compiled from herbarium specimens held at NSW.

$\begin{array}{lrcccc}\text { Taxon } & \mathbf{n} & \text { mean } & \text { range } & \text { S.D. } & \text { ovary exposed? } \\ \text { acerosa } & 22 & 3.53 & 2.5-4.4 & 0.50 & \text { no } \\ \text { arborea } & 4 & 9.33 & 8.0-10.3 & 0.84 & \text { yes } \\ \text { asperula } & 7 & 2.67 & 2.1-3.1 & 0.31 & \text { no } \\ \text { chamaepeuce } & 42 & 3.00 & 2.2-4.3 & 0.50 & \text { no } \\ \text { chamaepitys } & 17 & 7.15 & 4.0-12.5 & 2.85 & \text { yes } \\ \text { glaucescens } & 10 & 4.09 & 3.4-4.9 & 0.55 & \text { no } \\ \text { isophylla } & 11 & 2.46 & 2.1-2.9 & 0.22 & \text { no } \\ \text { lanceolata } & 38 & 3.58 & 2.6-4.5 & 0.49 & \text { no } \\ \text { laurina subsp. laurina } & 19 & 4.96 & 3.9-6.3 & 0.69 & \text { no } \\ \text { levis } & 24 & 4.12 & 3.0-5.3 & 0.53 & \text { no } \\ \text { microphylla } & 5 & 2.56 & 2.2-3.3 & 0.40 & \text { no } \\ \text { mollis } & 93 & 3.31 & 2.4-4.5 & 0.44 & \text { no } \\ \text { myrtilloides subsp. myrtilloides } & 16 & 3.34 & 2.7-3.8 & 0.36 & \text { no } \\ \text { nutans } & 17 & 2.82 & 2.3-3.6 & 0.38 & \text { no } \\ \text { oblongata } & 12 & 3.65 & 3.3-4.0 & 0.30 & \text { no } \\ \text { oxycoccoides } & 10 & 2.37 & 1.9-2.7 & 0.29 & \text { no } \\ \text { pinifolia } & 23 & 3.47 & 2.9-4.2 & 0.35 & \text { no } \\ \text { silvatica } & 20 & 4.16 & 2.6-5.0 & 0.67 & \text { no } \\ \text { subvelutina } & 8 & 5.34 & 4.1-6.3 & 0.70 & \text { no } \\ \text { virgata } & 23 & 2.57 & 1.9-3.7 & 0.38 & \text { no } \\ & & & & & \end{array}$




\section{Floral attractants}

The tepals of all species observed are yellowish (old ivory) to yellowish orange in colour to the human eye. Dull amber or rusty tones are due to the darker-coloured, simple trichomes on the tepals. Persoonia arborea, P. laurina, P. subvelutina and P. silvatica have glossy, white anthers. In all other taxa examined the anthers are yellowish to the human eye often turning a dried mustard colour with age. The tepals of $P$. glaucescens were observed to change from a deep apricot to a light, straw yellow as the individual flowers age. The yellow tepals of $P$. lanceolata become progressively paler with age.

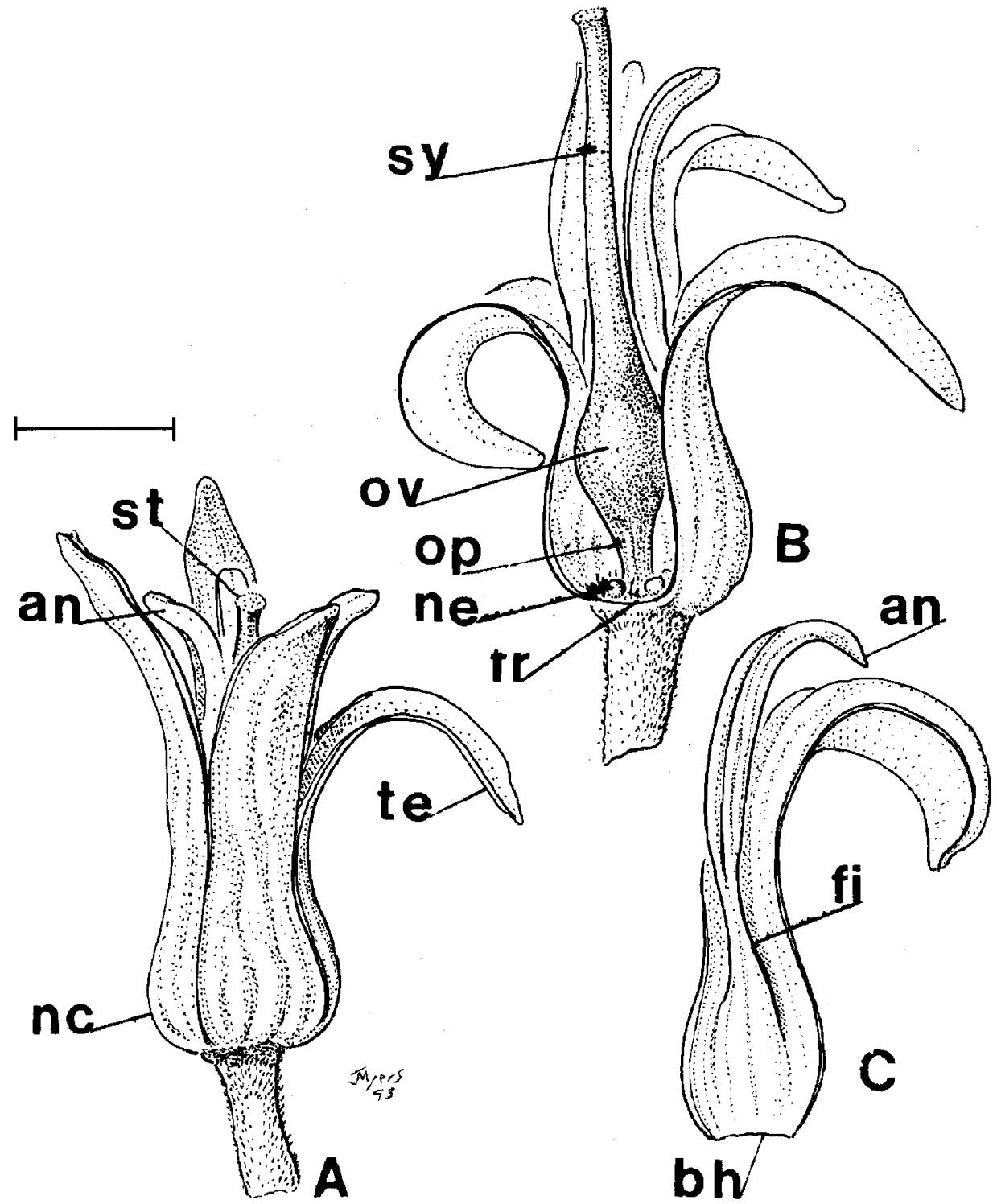

Fig. 1. Flower of Persoonia pinifolia. A, whole flower with anther bases clasping the style; $B$, tepal removed showing the interior of the nectar chamber; $C$, coalescence of tepal and stamen $(\mathrm{scale}=2 \mathrm{~mm})$. an $=$ anther; $\mathrm{bh}=$ basal hinge; $\mathrm{fi}=$ filament; $\mathrm{fr}=$ floral receptacle; $\mathrm{nc}=$ nectar chamber; ne = nectary; op = gynophore; ov = ovary; st = stigma; sy = style. 
The Neutral Red Test indicated that the flowers of seven species stain positively for the presence of osmophoric activity (Table 4). The floral sites showing the most consistent pattern of staining for all seven species were the stigmas, nectar glands and anthers. In P. levis and P. oxycoccoides the wrinkled margins of the tepal lobes also stained deeply. In four species the trichomes on the outsides of the tepals showed a strong response to the stain (Table 4). The staining of floral organs with Neutral Red varied between $P$. mollis subspecies.

Flowers sampled on their branches and flowers kept in sealed vials showed four, overlapping scent types. A vanilla-musky scent was produced by P. silvatica and $P$. subvelutina. This is such a strong odour that it is still recognisable several metres away from the flowering shrub. The intensity of the odour does not become noticeably

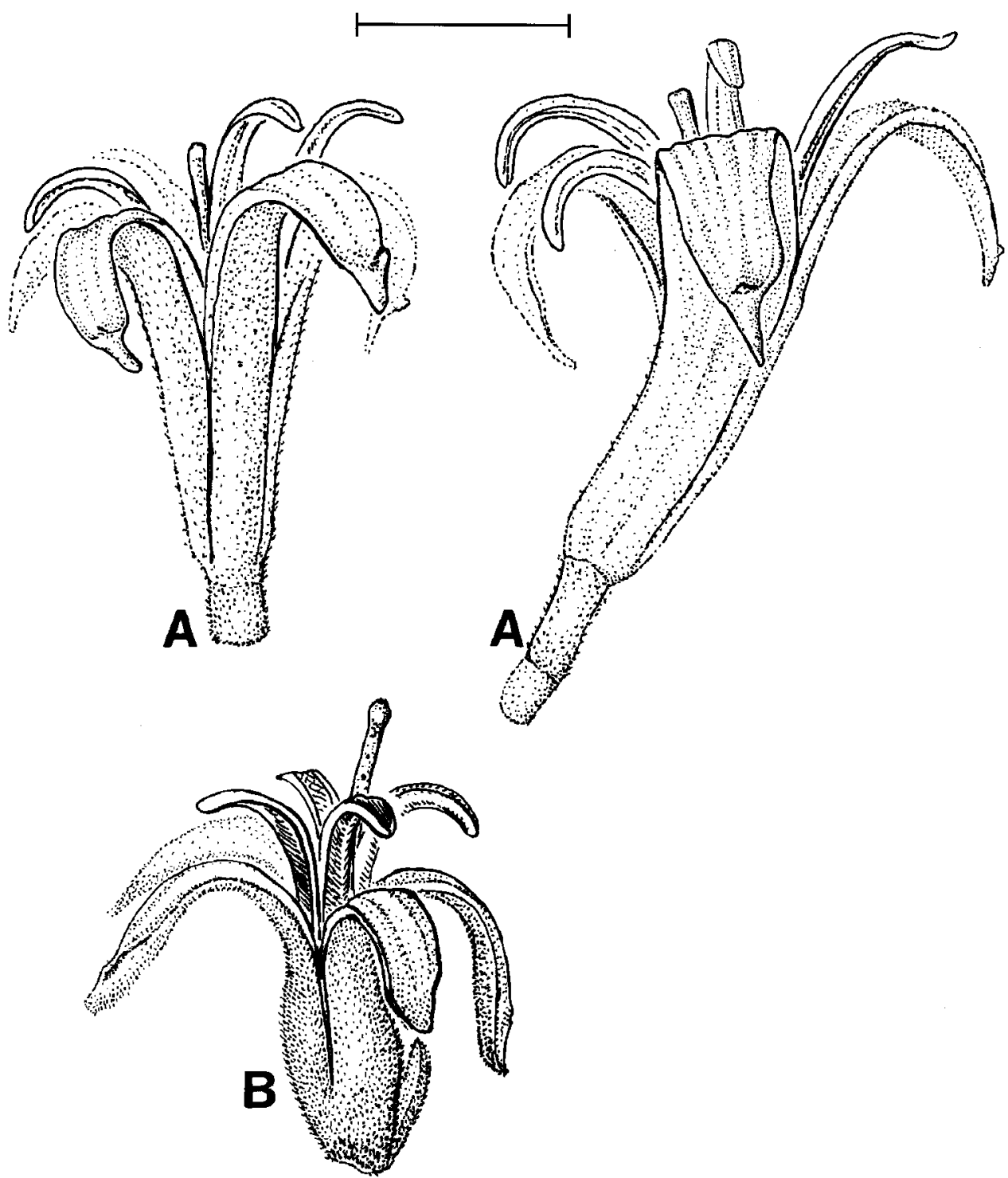

Fig. 2. Variation in the length and shape of the perianth tube. A, persoonia arborea; $\mathbf{B}$, persoonia levis (scale $=5 \mathrm{~mm}$ ). 
stronger or different upon bottling for less than 30 minutes. The scent is reminiscent of vanilla extract with undertones of commercial musk colognes. The floral odour of these two species is surprisingly similar to many of the neotropical, day-flowering orchids in the genus Encyclia (e.g. E. cordigera).

The floral-yeasty scent of $P$. mollis and $P$. pinifolia is far weaker to the human nose when sampled in situ, producing a faint but pleasantly honey-like perfume reminiscent of Boronia, Plumeria or Narcissus flowers. Once bottled, these sweet floral odours become more pronounced within 30 minutes, but a yeast-like undertone can also be discerned. Persoonia glaucescens and $P$. isophylla also produce these weak scents but after bottling they seem closer to the vanilla-musk scent described above.

The fruity scent of P. lanceolata and P. oxycoccoides is also weak to the human nose when sampled in situ. Upon bottling the concentrated odour is similar to ripe, commercial bananas or cherries.

The 'green' smell of $P$. katerae and $P$. cornifolia is not discernible in situ and only becomes apparent 20-30 minutes after bottling. At that time the concentrated odour is reminiscent of freshly chopped, green beans or unripe tomatoes.

If flowers of all the above species are bottled for 60 minutes or more, their original odour degrades into the green smell.

\section{Nectar}

Field examinations and lab dissections showed that nectar droplets are secreted by each of the four receptacular nectaries surrounding the gynoecium and flanking each of the four tepals (Fig. 1). Nectar droplets cling to the large nectaries or adhere to the smooth bases of the inner surfaces of the tepals when secretions are particularly copious. Nectar is usually retained in a restricted chamber formed by the base of the perianth, floral receptacle and ovary stalk. Access to the chamber is blocked by the ovary, which forms a roof, and by the degree of constriction of the tepals and anther bases (Fig. 1). Flowering branches bagged overnight contained nectar the following morning. Less than one microlitre of nectar could be removed from each individual flower of any species at any time, with the exception of P. silvatica and P. subvelutina. Bagged overnight, individual flowers of these two species produced a maximum of five microlitres of nectar. The sugar analyses of the nectar of $P$. subvelutina was $93.1 \%$ sucrose, $3.8 \%$ glucose and $3.1 \%$ fructose. P. pinifolia was $97.9 \%$ sucrose, $1.2 \%$ glucose and $0.9 \%$ fructose.

Table 4. Scent descriptions of Persoonia spp. and results of Neutral Red tests.

$\begin{array}{lccccccc}\text { TAxoN } & \text { scent type } & \text { stig } & \text { nect } & \text { ant } & \text { tep } & \text { tepm } & \text { trc } \\ \text { cornifolia } & \text { green smell } & ++ & ++ & ++ & + & + & ++ \\ \text { isophylla } & \text { sweet-yeasty } & + & ++ & ++ & + & + & +- \\ \text { katerae } & \text { green smell } & + & ++ & + & ++ & +- & + \\ \text { levis } & \text { green smell } & ++ & ++ & ++ & + & ++ & ++ \\ \text { mollis subsp. ledifolia } & \text { sweet-yeasty } & ++ & ++ & ++ & - & + & ++ \\ \text { mollis subsp. nectens } & \text { sweet-yeasty } & + & ++ & ++ & ++ & +- & + \\ \text { oxycoccoides } & \text { fruity } & ++ & ++ & ++ & + & ++ & \mathrm{NA} \\ \text { pinifolia } & \text { sweet-yeasty } & ++ & ++ & + & +- & +- & ++\end{array}$

${ }^{*}$ stig = stigma; nect $=$ nectary; ant $=$ anther; tep = glabrous inner surface of the tepal; tepm = tepal margins; trc = trichomes on the outer surface of the tepal and along the tepal margins; $N A=$ not applicable - the flowers of this species are glabrous. 


\section{Forager diversity, density and gender}

A collection of 531 foraging insects was made on the flowers of 19 Persoonia species and the hybrid $P$. acerosa $\times$ P. levis. The collection contained one beetle genus, four wasp taxa and 11 bee genera representing five families (Table 5). Of the five families of bees the Colletidae and Halictidae are classified as short-tongue bees, due to the reduced length of the glossa (Michener 1979). Bees were the dominant foragers, comprising almost $99 \%$ of the collection. All bee taxa collected, excluding Apis mellifera, were Australian native taxa.

Bees in the genus Leioproctus (subgenus Cladocerapis; Colletidae) were collected on 17 of the 20 Persoonia species and on the hybrid P. acerosa $\times$ P. levis (Table 5). These bees made up over $47 \%$ of the total catch. Male and female bees in this subgenus were collected while they probed Persoonia flowers for nectar. Five of the nine species described in this subgenus in eastern Australia (Maynard 1992) were identified. The most commonly collected species in subgenus Cladocerapis was L. speculiferus which was collected on 12 Persoonia species. Leioproctus bipectinatus was collected least often and was confined to the Nerriga site (Table 5 and Appendix).

All bees collected on Persoonia flowers, with the exception of Leioproctus and Nomia species, were females. Specimens of Apis mellifera and Trigona belonged to the worker caste. Collections of males of Nomia and Leioproctus species on Persoonia flowers never exceeded collections of females although the ratio of male to female $L$. rayment $i$ was 0.50 (and see Table 7).

Similarities between the diversity and density of floral foragers on different Persoonia species were greatest when Persoonia species shared the same site and an overlapping floral phenology. For example, foragers were sampled three times at the Hilltop site. Leioproctus carinatifrons, $L$. incanescens and $L$. speculiferus were the dominant native foragers on each of three Persoonia species (Tables 5 and 7). Bees in subgenus Cladocerapis comprised $91 \%$ of the total catch at the Hilltop site.

Floral foragers collected on $P$. mollis and P. microphylla at the Nerriga site represent only a single sampling. In both species, though, Leioproctus incanescens was the dominant forager. Nerriga was the only site at which the uncommon L. bipectinatus was collected and it was found on both Persoonia species (Table 5 and see above).

Persoonia pinifolia and $P$. isophylla are treated as sister species (Weston \& Johnson 1991) but these two taxa were sampled at three, separate sites where only one species was present. Flowers of the P. pinifolia population were sampled for floral foragers five times over two seasons. The $P$. isophylla sites were each sampled three times in one season. The majority of native bees foraging on $P$. pinifolia belonged to long tongue families Anthophoridae, Megachilidae and Apidae. Only 7\% of the Hymenoptera collected on $P$. pinifolia were colletids in Leioproctus subgenus Cladocerapis (L. sp., L. incanescens, L. raymenti and L. speculiferus) (Table 5).

In contrast, Leioproctus (Cladocerapis) speculiferus was the dominant forager on P. isophylla, comprising over $40 \%$ of the total catch. With the exception of the naturalised Apis mellifera (Apidae), long-tongue foragers were not captured on the flowers of $P$. isophylla. Instead, the short-tongue Nomia species (Halictidae) were more common (Table 5).

\section{Pollen load analyses}

The Zonitis beetle and most of the wasps collected on Persoonia flowers did not carry Persoonia pollen (Table 5). Hylaeus bees foraged for pollen on Persoonia anthers by swallowing grains so deposition of Persoonia pollen on the bee's body was usually negligible. Apis mellifera and Trigona carbonaria were the only insects observed to mould Persoonia pollen into smooth, nectar-dampened pellets to be carried on the 
corbiculae of the hind legs. All other female bees that carried significant loads of Persoonia pollen were observed to transfer pollen to scopal hairs on the hind legs and/or ventral hairs at the base of the abdomen (Fig. 3).

Male Leioproctus species (Cladocerapis and Filiglossa) also carried loads of Persoonia pollen on their bodies (Table 7). Pollen was deposited randomly on the head and thorax since males lack scopae and were never observed foraging actively on the anthers (see below). With the exception of males of Leioproctus raymenti, females of four Leioproctus species carried proportionately heavier loads of Persoonia pollen.

Almost $80 \%$ of all insects captured on the flowers of Persoonia species carried significant loads of Persoonia pollen. The number of insects carrying pure loads of Persoonia pollen was 55\% higher than the number of insects caught carrying Persoonia pollen mixed with the pollen of one, or more, co-blooming taxa (Table 5). Analyses of 142 bees carrying mixed loads showed that seven pollen types, other than Persoonia, could be recognised (Fig. 4, 5; Table 9). Acacia polyads were the only taxa that could be recognised as coming from flowers lacking functional floral nectaries (Bernhardt 1989). Of these seven recognisable types the pollen of Myrtaceae was most often found on bees carrying mixed loads (Table 9). Mixed loads of pollen were common on female Leioproctus (Cladocerapis) species although this subgenus has been regarded as oligolectic (Maynard 1992 and 1994).

Of the 424 bees found to carry Persoonia pollen, $4.7 \%$ were detected carrying the pollen of more than one Persoonia species in the same pollen load. Specifically, each bee recorded as carrying more than one Persoonia species carried more than 25 grains of each Persoonia species. At the two sites in which interspecific foraging by bees was recorded, $28 \%$ of the bees examined carried the pollen of more than one Persoonia species (Table 8 ).

\section{Foraging behaviour and contact with the stigma}

The mode of nectar collection by different bee taxa correlated with body lengths. Both bees and wasps with bodies greater than $6 \mathrm{~mm}$ long first landed on the anthers or tepal apices. The insect then depressed one or two tepals and inserted its head and thorax down the floral tube to probe within the nectar chamber (Table 6).

Depression of the tepals could occur in two ways. In most cases the bee or wasp depressed the tepal while its head faced the style. In fewer cases we observed that the insect would cling to the style or anthers with its legs and then push its head up under the tepal so its eyes faced the tepal and not the style. This second mode of entering the floral tube was observed most often when bees foraged on Persoonia species with nodding flowers.

Bees less than $6 \mathrm{~mm}$ long did not or could not depress the tepals (Table 6). Homalictus species, Hylaeus species and Trigona carbonaria were observed to collect pollen after grasping individual anthers. They were not observed to either enter the floral tube or attempt to rob nectar by puncturing the base of the nectar chamber. These bees were so small that they did not usually contact the Persoonia stigma while foraging for pollen.

Leioproctus species in subgenus Filiglossa have much elongated maxillary and labial palps with long, stiff, segmented hairs ornamenting the apices of the maxillary galeae (Fig. 6; Maynard 1994). Females were observed to forage actively on anthers for pollen, retaining grains in their scopal hairs. Females were also observed inserting their filiform mouthparts between tepals at the apex of the 'closed' floral tube (cf. Maynard 1995). Females were not observed to contact the stigmas regularly while 'fishing for nectar' in this manner as the bee's body was usually shorter than the protruding tip of the anthers. Males observed foraging on $P$. silvatica inserted their 
Table 5. Pollen load analyses of insect foragers collected on Persoonia species.

\section{Plant and insect taxon}

$P$. acerosa $\times P$. levis

Lejoproctus raymenti

P. arborea

Callomelitta sp

Exoneura spp.

Leioproctus (Filiglossa) davisi Nomia sp.

subtotals

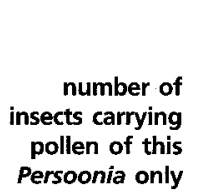

number of insects carrying pollen of this Persoonia + other spp. (including other Persoonia)

$\begin{array}{rr}\text { number of } & \\ \text { insects carrying } & \\ \text { pollen of other } & \text { number of } \\ \text { spp. only } & \text { insects } \\ \text { (including other } & \text { carrying } \\ \text { Persoonia) } & \text { no pollen }\end{array}$

0

0

0

10

10

P. asperula

Leioproctus (Filiglossa) sp.

L. speculiferus

subtotals

P. chamaepitys

Chalicodoma sp.

Eumenid wasp

Hylaeus sp.

Leioproctus raymenti

subtotals

P. chamaepeuce

Leioproctus (Filiglossa) sp.
$P$ glaucescens

Apis mellifera

Callomelitta sp.

Exoneura sp.

Leioproctus carinatifrons

L. incanescens

L. speculiferus

subtotals

P. isophylla

Apis mellifera

Hylaeus sp.

Lasioglossum brazieri

Leioproctus (filiglossa) sp.

L. speculiferus

Nomia spp.

Sphecid wasps

subtotals

P. lanceolata

Exoneura sp.

Leioproctus (Filiglossa) sp.

L. carinatifrons

L. incanescens

L. speculiferus

subtotals

P. laurina

Leioproctus

(Cladocerapis) sp.

0

Leioproctus carinatifrons

P. mollis

Coleoptera

Zonitis

$\begin{array}{ll}0 & 0 \\ 0 & 0 \\ 5 & 6 \\ 1 & 2 \\ 9 & 3\end{array}$

Hymenoptera

Amegilla spp.

Apis mellifera

Chalicodoma spp.

Exoneura spp. 


\begin{tabular}{|c|c|c|c|c|}
\hline Plant and insect taxon & $\begin{array}{r}\text { number of } \\
\text { insects carrying } \\
\text { pollen of this } \\
\text { Persoonia only }\end{array}$ & $\begin{array}{r}\text { number of } \\
\text { insects carrying } \\
\text { pollen of this } \\
\text { Persoonia + other } \\
\text { spp. (including } \\
\text { other Persoonia) }\end{array}$ & $\begin{array}{r}\text { number of } \\
\text { insects carrying } \\
\text { pollen of other } \\
\text { spp. only } \\
\text { (including other } \\
\text { Persoonia) }\end{array}$ & $\begin{array}{r}\text { number of } \\
\text { insects } \\
\text { carrying } \\
\text { no pollen }\end{array}$ \\
\hline \multicolumn{5}{|l|}{ P. mollis (continued) } \\
\hline Homalictus urbanus & 0 & 1 & 0 & 0 \\
\hline Lasioglossum repraesentans & 0 & 0 & 1 & 0 \\
\hline Leioproctus (Cladocerapis) sp. & 0 & 0 & 0 & 1 \\
\hline L. bipectinatus & 0 & 1 & 0 & 0 \\
\hline L. carinatifrons & 3 & 1 & 0 & 0 \\
\hline L. incanescens & 11 & 15 & 0 & 0 \\
\hline L. speculiferus & 11 & 16 & 3 & 1 \\
\hline L. (Filiglossa) sp. & 1 & 0 & 0 & 0 \\
\hline Nomia spp. & 1 & 1 & 7 & 1 \\
\hline Ichneumonid wasp & 0 & 1 & 0 & 0 \\
\hline subtotals & 42 & 47 & 11 & 11 \\
\hline \multicolumn{5}{|l|}{ P. microphylla } \\
\hline Amegilla sp. & 1 & 0 & 0 & 0 \\
\hline Apis mellifera & 0 & 2 & 0 & 0 \\
\hline Leioproctus bipectinatus & 2 & 0 & 0 & 0 \\
\hline L. incanescens & 4 & 4 & 0 & 0 \\
\hline L. speculiferus & 1 & 0 & 0 & 0 \\
\hline subtotals & 8 & 6 & 0 & 0 \\
\hline
\end{tabular}

P. myrtilloides subsp. myrtilloides Exoneura spp.

Hylaeus spp.

Homalictus holochorus

Leioproctus (Cladocerapis) sp.

L. carinatifrons

L. raymenti

L. speculiferus

Odyneurus sp.

Trigona carbonaria

subtotals pollen of this Persoonia only

spp. (including

other Persoonia)

\section{insects}

0
0
1
0
0
0
1
0
1
0
11

0
0
0
0
0
0

P. nutans

Chalicodoma spp.

Leioproctus (Cladocerapis) sp.

$L$ incanescens

subtotals

\section{P. oblongata}

Apis mellifera

Homalictus urbanus

Lasioglossum instabilis

Leioproctus raymenti

Trigona carbonaria

subtotals

\section{$P$ oxycoccoides}

Apis mellifera

Exoneura spp.

Leioproctus speculiferus

subtotals

$\begin{array}{ll}0 & 3 \\ 0 & 2 \\ 0 & 2 \\ 0 & 7\end{array}$

$\begin{array}{ll}3 & 1 \\ 2 & 0 \\ 2 & 1 \\ 7 & 2\end{array}$

1
0
1
2

0

P. pinifolia

Apis mellifera

Chalicodoma spp.

Exoneura spp.

Leioproctus (Parasphecodes) sp.

L. (Filiglossa) spp.

L. (Cladocerapis) sp.

L. incanescens

L. raymenti

L. speculiferus

Trigona carbonaria

Sphecid wasp

subtotals

subtotals 
Table 5 (continued). Pollen load analyses of insect foragers collected on Persoonia species.

Plant and insect taxon

number of
insects carrying
pollen of this
Persoonia + other
spp. (including
other Persoonia)

\author{
number of \\ insects carrying \\ pollen of other \\ spp. only \\ (including other \\ Persoonia)
}

P. subvelutina

Callomelitta sp.

Chalicodoma sp.

Exoneura spp.

Leioproctus (Filiglossa) sp.

L. speculiferus

subtotals

insects carrying
pollen of this

Persoonia only

\section{P. silvatica}

Leioproctus (Cladocerapis) sp

L. (Filiglossa) spp.

L. incanescens

L. speculiferus

subtotals

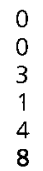

1
1
3
0
2
7

$\begin{array}{ll}0 & 0 \\ 0 & 0 \\ 0 & 0 \\ 0 & 0 \\ 0 & 0 \\ 0 & 0\end{array}$

P. virgata

Amegilla sp.

Apis mellifera

Exoneura spp.

Homalictus urbanus

Hylaeus spp.

Leioproctus incanescens

L. speculiferus

Trigona carbonaria

subtotals

grand totals

foraging ratios

Total Number of Foraging Insects $=531$

0.520

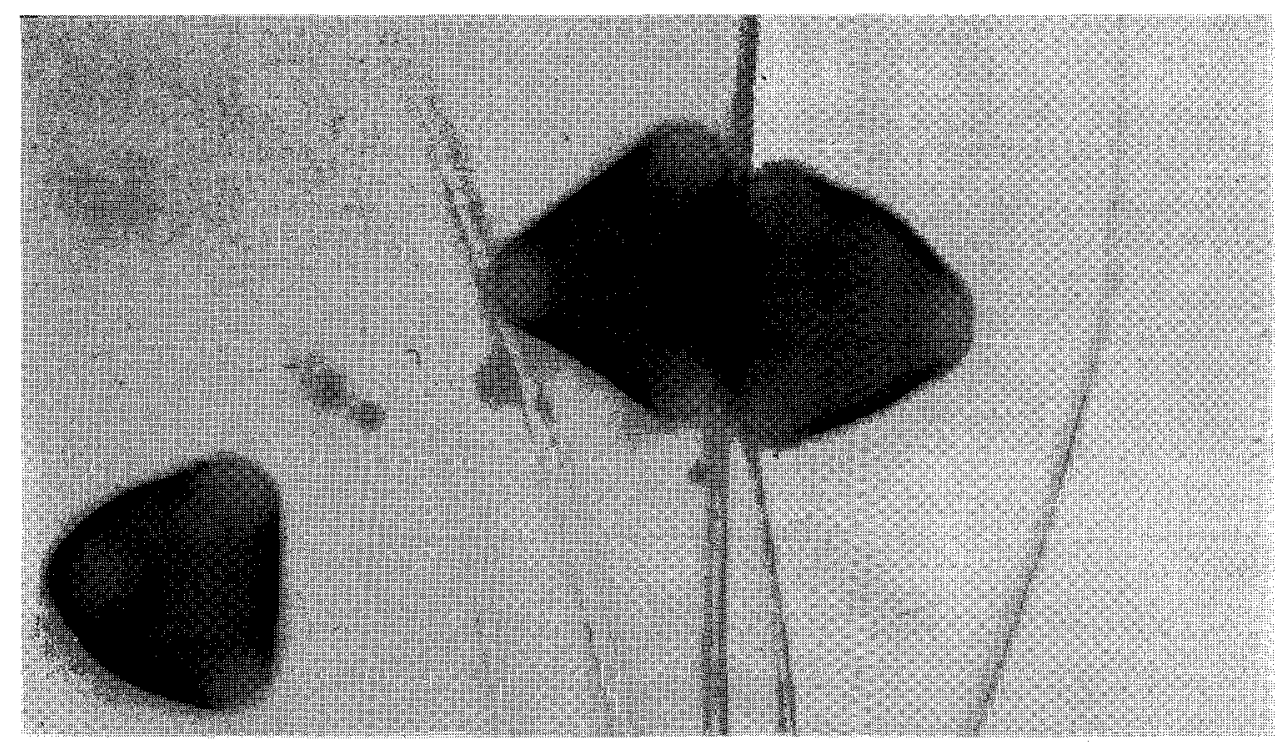

Fig. 3. Pollen of Persoonia mollis subsp. livens in ventral hairs of a female Leioproctus incanescens, $\times 509$. 
mouthparts between tepal seams towards the base of the nectar chamber. However, as males in the subgenus Filiglossa were observed to actually avoid Persoonia anthers they were not significant carriers of Persoonia pollen (Tables 5 and 7).

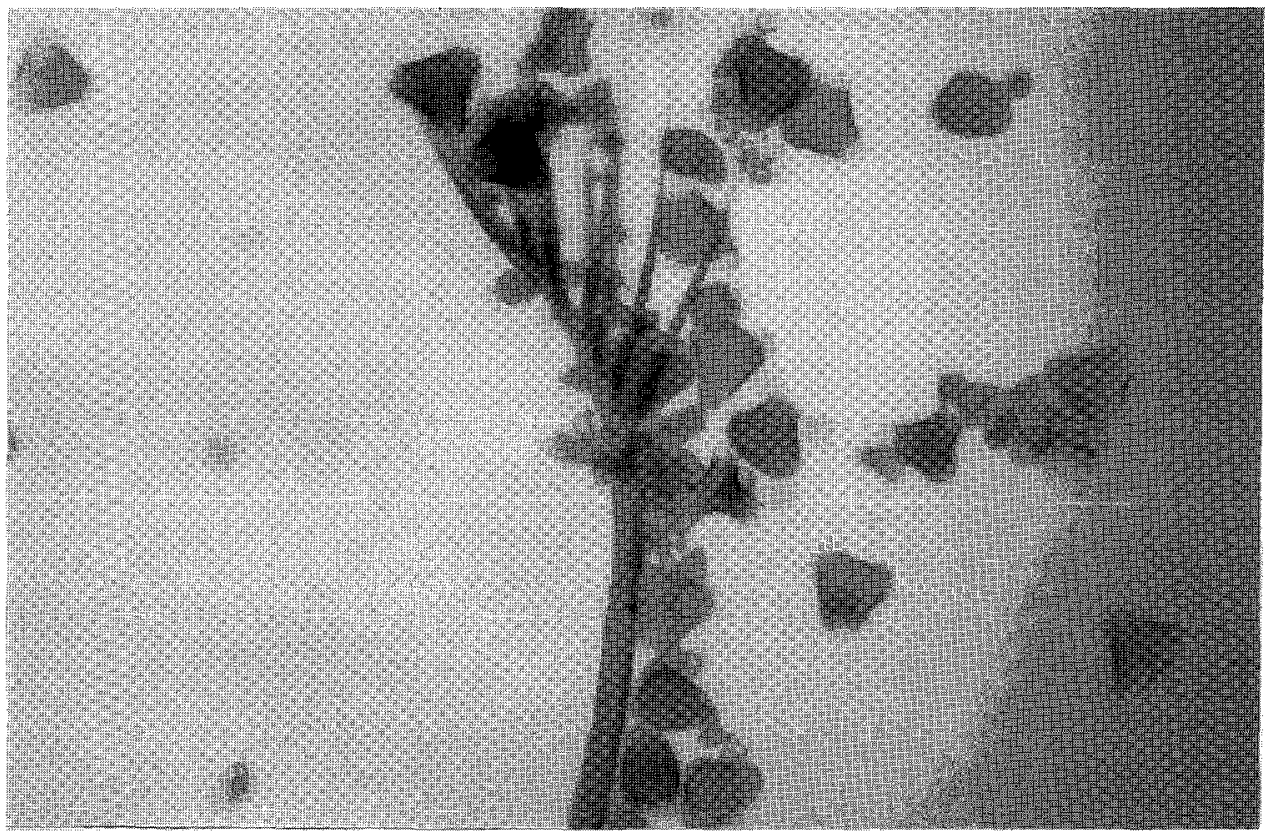

Fig. 4. Branched scopal hair of a female Leioproctus speculiferus carrying pollen of Persoonia silvatica (large triangles) and Eucalyptus spp (small triangles), $\times 178$.

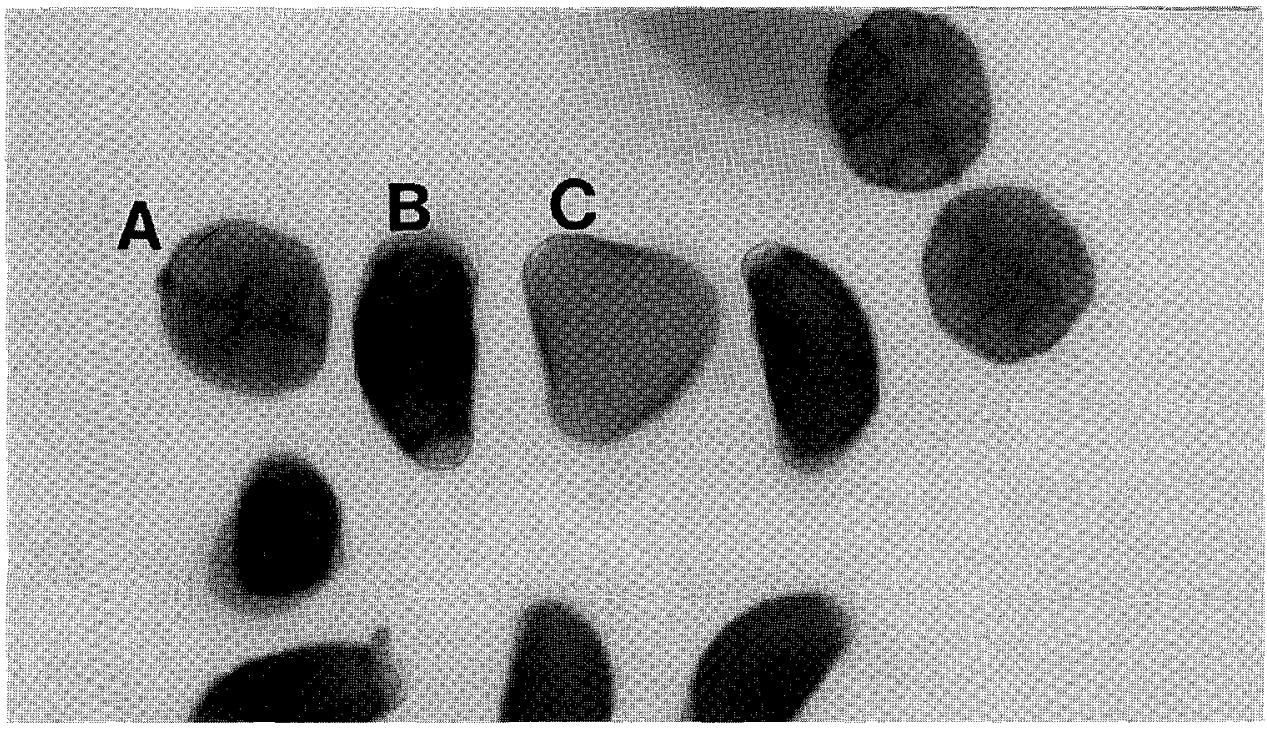

Fig. 5. Section of a mixed load of pollen taken from a female Leioproctus carinatifrons collected on the flower of $P$. mollis subsp. nectens. A, polyad of Acacia spp; B, pollen of Banksia; C, pollen of Persoonia mollis, $\times 297$. 
Table 6. Comparative sizes and foraging behaviours of insects on Persoonia species.

Insect taxon

Bees

Anthophoridae

Amegilla spp.

Exoneura spp.

Apidae

Apis mellifera

Trigona carbonaria

Colletidae

Callomelitta spp.

Hylaeus spp.

Leioproctus (Cladocerapis)

L. bipectinatus

$L$. carinatifrons

L. incanescens

L. raymenti

L. speculiferus

unidentified Cladocerapis

Leioproctus (Filiglossa)

L. davisi

unidentified Filiglossa

Halictidae

Homalictus holochorus

Homalictus urbanus

Lasioglossum (Chilalictus)

L. brazieri

L. instabilis

L. repraesentens

Lasioglossum (Parasphecodes)

Lasioglossum sp.

Nomia spp.

Megachilidae

Chalicodoma spp.

13

\section{Wasps}

Ichneumonid sp.

Eumenid sp.

Odyneurus sp.

Sphecid spp.

\section{Coleoptera}

Zonitis sp.

n

47

3

11

17

34

3

1

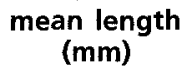
active pollen collector

depresses

tepals

12.5

6.3

13.6

4.5

10.5

10.4

10.5

9.8

9.8

9.0

NM

5.3

10.0

8.0

8.0

11.0

8.6

11.0

13.0

10.0

15.0
9.0

5.0

6.0

4.0

9.6

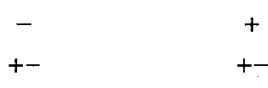

$+\quad+$

$+\quad-$

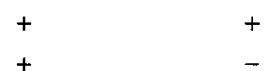

$\begin{array}{ll}+ & + \\ + & + \\ + & + \\ + & + \\ + & + \\ + & \end{array}$

$+$

$+$

$+\quad+$

$+\quad+$

- +

$+\quad+$

$+-\quad+$

12.0

* Length combines males and females but columns on behaviour refer to females exclusively. NM Not measured but estimated $<7 \mathrm{~mm}$. 
Amegilla, Chalicodoma and the larger wasp taxa were observed to depress the tepals and probe for nectar. They were not observed foraging on anthers or making active collections of pollen (Tables $5 \& 6$ ).

Apis mellifera, Exoneura species and Leioproctus (Cladocerapis) species were the only larger bees collected on Persoonia flowers that were regularly observed both to contact stigmas while foraging and to carry significant loads of Persoonia pollen (Tables 5, 6, 8 ,9). Depositions of Persoonia pollen on these insects was the result of active and passive collection. Females in all three bee taxa were observed removing pollen from dehiscent anthers. All three taxa continued to contact the anthers and stigmas while depressing tepals to probe for nectar. Although these bees were the only common and consistent pollinators of Persoonia species, they also comprised over $83 \%$ of the 142 insects found to carry the pollen of Persoonia spp. mixed with the pollen of at least nine other pollen types (Table 9).

Workers of Apis mellifera and females of Exoneura species scraped Persoonia anthers with their forelegs, depositing pollen in their corbiculae or scopae respectively. Although males of Leioproctus (Cladocerapis) species were never observed to forage actively on Persoonia anthers, their bodies did contact the anthers when they depressed the tepals to probe for nectar (Table 6).

Females of Leioproctus carinatifrons, L. incanescens and L. speculiferus (Cladocerapis) showed the same stereotyped mode of floral foraging on P. lanceolata, P. mollis and P. glaucescens at the Hilltop site (cf. Maynard 1995). Typically, the bee landed on a flower, depressed a tepal, inserted its body halfway down the floral tube and probed for nectar. The head of a Cladocerapis bee contacted the style of the Persoonia flower and appeared to slide down the style as the bee pushed itself down the floral tube.

Table 7. Comparative loads of Persoonia pollen carried by Leioproctus species of different genders.

Bee taxon and gender

Leioproctus (Cladocerapis)

L. bipectinatus

males

females

L. carinatifrons

males

females

L. incanescens

males

females

L. raymenti

males

females

L. speculiferus

males

females

Leioproctus (Filiglossa)

males

females
Number of Persoonia Grains Carried

$\begin{array}{rrr}0-24 & 25-50 & 50-100\end{array}$

0

0

0

0

1

1

0

2

1

6

8

11

0

0

3

0

0

0

0

0

$\begin{array}{lll}0 & 1 & 4\end{array}$

$\begin{array}{lll}9 & 4 & 11\end{array}$

$\begin{array}{ccc}9 & 4 & 11 \\ 6 & 10 & 99\end{array}$

1

2
1

26
2

53

4

4

0

2

3

12

0

16 
After removing its body from the floral tube the bee reversed its position and clasped the single anther fused to the tepal it had first depressed. The bee then inserted the clawed tip of the tarsus of each foreleg into the apices of each longitudinal slit on opposite lobes of the same anther. The bee depressed its body forcing each pair of claws to slide down the full length of each longitudinal slit until they reached the base. The two claws that tip each tarsus expanded, raking pollen from the interior of each slit. The bee then retracted each tarsus (the claws now filled with pollen) and transferred the pollen to the second pair of legs. The second pair then transferred the pollen to the scopal hairs on the hind legs and ventral portion of the abdomen (cf. Maynard 1995).

In the majority of cases observed, after the bee collected pollen from one anther it would repeat the same nectar and pollen foraging behaviour by selecting a second,

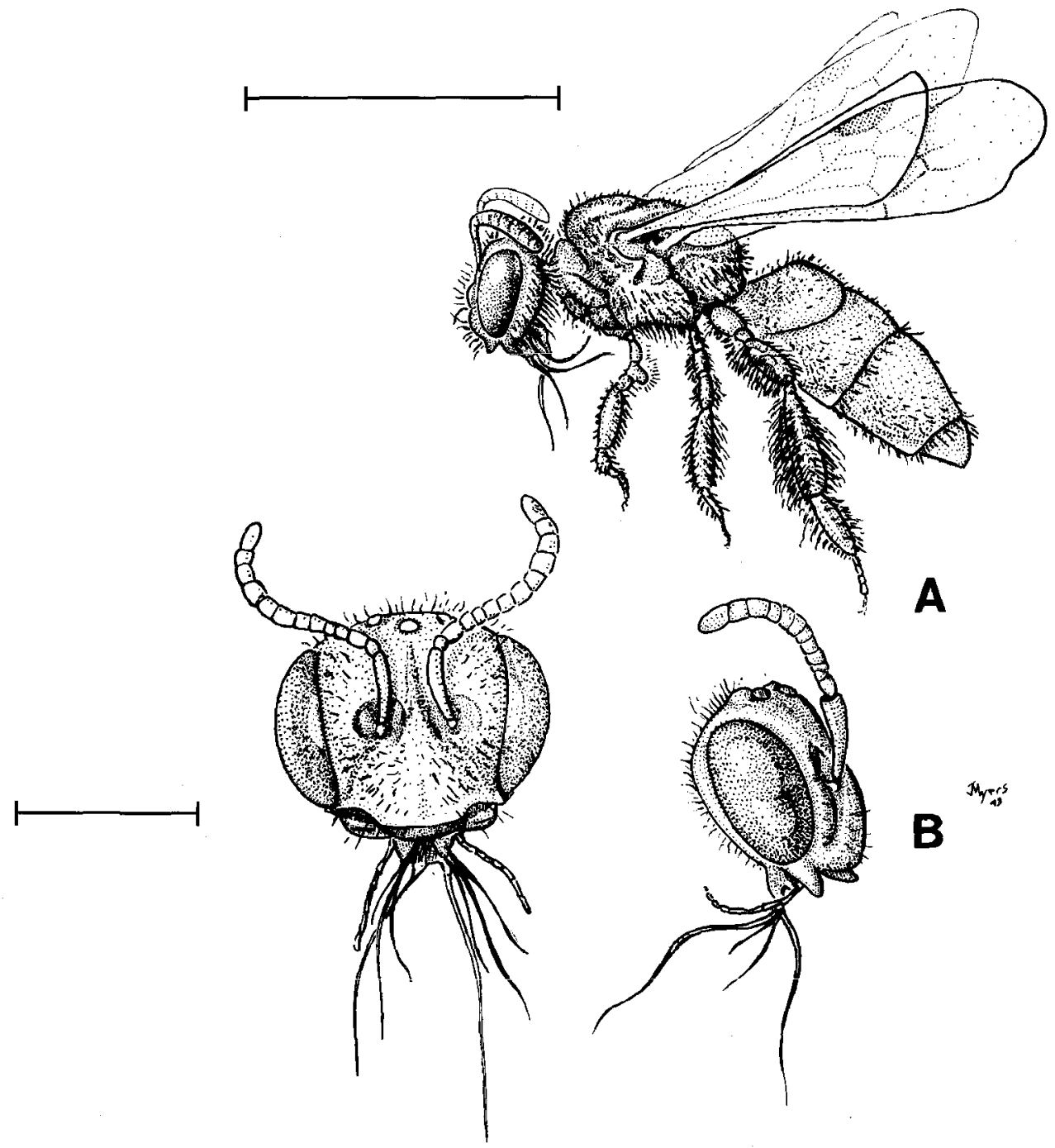

Fig. 6. Female of Leioproctus filamentosa. A, whole insect showing scopal brushes on hind legs (scale $=2.5 \mathrm{~mm}$ ); $\mathbf{B}$, head in lateral and frontal views, showing elongated mouthparts (scale $=1 \mathrm{~mm}$ ). 
third or fourth tepal on the same flower. Less frequently, it would fly to another flower or leave the site. In each case observed the bee always depressed the tepal and probed for nectar before harvesting pollen from the tepal's anther.

Variations on this mode of behaviour were observed at all sites in which female Leioproctus (Cladocerapis) species were common foragers. However, it was only at the Hilltop site that we observed that a Cladocerapis female would regularly depress all four of the tepals and rake pollen from each of the four anthers on the same flower. It contacted the stigma in two ways while foraging on the same flower. First, the bee's thorax and abdomen made dorsal contact with the stigma while foraging for nectar. Second, the thorax and abdomen made ventral contact with the stigma when the bee extricated herself from the floral tube and reversed herself to confront the anther. This movement provided the stigma with direct contact with the pollen laden, scopal hairs on the third pair of legs and with the 'apron' of hairs clothing the base of the underside of the abdomen.

While bees in subgenus Cladocerapis and Exoneura species were the dominant pollinators of most Persoonia species they were too small to follow consistently from plant to plant within the study site. We did observe at the Big Badja Hill, Carrington Falls, Gungulla (Waterfall), Hilltop, Mt Tomah, Peats Ridge and Tianjara Falls sites that these two bee taxa would leave the flowers of one Persoonia shrub to visit those of its nearest neighbour. This occurred most often when the branches of different shrubs overlapped.

\section{Discussion}

Bees and wasps appear to be the major foragers on the flowers of Persoonia species native to eastern Australia. Taxa representing five out of the seven families of bees recorded in Australia (sensu Michener \& Houston 1991) were collected on 19 of the 20 species and one of the two hybrids in this study. However, only $23 \%$ of the insect taxa collected on Persoonia were both frequent visitors and consistent pollen vectors contacting dehiscent anthers and receptive stigmas while foraging for pollen and/or nectar. Field observations, insect collections and pollen load analyses indicate that only four or five out of the 26 taxa of Hymenoptera may be regarded currently as common or important pollinators of Persoonia species. This includes Exoneura species, perhaps three out of five Leioproctus (Cladocerapis) species and, possibly, the introduced honeybee (Apis mellifera).

The role of the naturalised, A. mellifera, as a cross-pollinator of Persoonia is difficult to interpret. Workers forage actively for Persoonia pollen and the body of the insect contacts the Persoonia stigma during pollen harvest or nectar consumption. However, as $A$. mellifera collects pollen it moistens grains with nectar and transfers them to corbiculae on the hindlegs moulding them into damp pellets. The sugar in the nectar will cause the grains to hydrate early so they will lose viability in transfer. The dense, claylike consistency of a corbicular pellet does not lend the compacted grains to easy transfer to a stigma particularly when they are now so compressed and then propped up on the hind tibia away from the lower, stigmatic surface. In contrast, female bees in the Anthophoridae, Halictidae and genus, Leioproctus, all carry their pollen loose in granular masses between hair tufts ornamenting the hindlegs and underside of the abdomen (Bernhardt 1984, 1989, 1995, Michener 1974). These bees may transfer Persoonia more easily when they scrape or rub the basal portion of their hindlegs or abdomens against the stigma while searching for nectar or dehiscent anthers. The effectiveness of naturalised, A. mellifera, as a pollinator of Persoonia would appear to depend on the quantity of grains that adhere to the bee's head and thorax but miss the combing process and transfer to the corbiculae. 
The flowers of Persoonia species in south-eastern Australia do not really appear to be examples of generalist melittophily as have been described, for example, in Australian Acacia species (Bernhardt 1989). That is, while many taxa within the Hymenoptera forage on the flowers of Persoonia in eastern Australia comparatively few visit the flowers frequently enough, and/or carry loads of Persoonia pollen directly to stigmas, to be regarded as primary agents of cross-pollination. In contrast, almost every bee (representing 27 taxa in four bee families) can collect pollen from the simple, brushlike, inflorescences of an Acacia species and then contact stigmas when it visits florets on a second inflorescence bearing receptive stigmas (Bernhardt 1989).

The way in which Leioproctus (Cladocerapis) species harvest pollen from Persoonia anthers is atypical but the actual act of cross-pollination in Persoonia species appears similar to many other bee-pollinated angiosperms offering both nectar and pollen as edible rewards. That is, the pollination of Persoonia flowers appears to depend ultimately on whether bees contact both anthers and stigmas regularly while foraging actively for nectar and/or pollen (Barth 1985; Kearns and Inouye 1993).

Although the perianth appears superficially tubular in all Persoonia species studied the floral architecture really functions more like a gullet flower. The functional

Table 8. Analyses of loads containing the pollen of four Persoonia spp. from bees collected at the Hilltop ( $P$. mollis subsp. nectens, $P$. glaucescens and $P$. lanceolata) and Nerriga ( $P$. mollis subsp. livens) sites.

Bee taxon and Persoonia sp. on which bee was caught

$P$. mollis subsp. livens

Apis mellifera

Exoneura sp. *

Leioproctus speculiferus*

subtotals

ratio of mixed foraging $=0.5$

$P$. mollis subsp. nectens

Homalictus urbanus

Leioproctus carinatifrons

L. incanescens

L. speculiferus

L. (Filiglossa) sp.

subtotals

ratio of mixed foraging $=0.29$

$P$. glaucescens

Apis mellifera

Leioproctus carinatifrons

L. incanescens

L. speculiferus

subtotals

ratio of mixed foraging $=0.31$

P. lanceolata

Exoneura sp.

Leioproctus carinatifrons

L. incanescens

L. speculiferus

L. (Filiglossa) spp.

subtotals

ratio of mixed foraging $=0.11$

grand total

grand ratio $=\mathbf{0 . 2 8}$

* Bees carried pollen of P. microphylla
Bees carrying pollen

of two Persoonia spp.

Bees carrying pollen of one Persoonia sp.

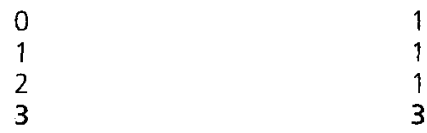

$\begin{array}{lc}0 & 1 \\ 1 & 3 \\ 0 & 3 \\ 4 & 5 \\ 0 & 2 \\ 5 & 1 \\ & 12\end{array}$

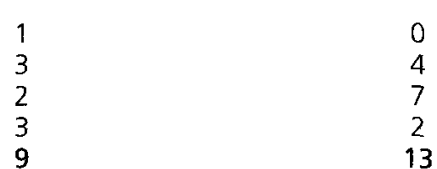

0

1

4

5

10

$\begin{array}{cc}1 & 2 \\ 3 & 22\end{array}$

20 
morphology of the perianth of a Persoonia flower resembles that of bilaterally symmetrical flowers of Lamiaceae and Scrophulariaceae where insects must depress the outer lobes of the corolla to gain access to nectar concealed at the base of a floral throat or spur (Faegri and van der Pijl 1979; Barth 1985). Therefore, a short-tongue colletid exceeding $9 \mathrm{~mm}$ appears to be as efficient a vector of Persoonia pollen as a long-tongue anthophorid with a mean body length of $7 \mathrm{~mm}$ or less. Both forage actively for pollen. Both are sufficiently dexterous, heavy and long enough to depress the tepals and then gather nectar from the base of the flower.

Consequently, floral presentation in Persoonia must exclude as dependable pollinators most of the smallest bees such as Trigona carbonaria and Leioproctus (Filiglossa) species. Their mouthparts reach the nectar chamber of most Persoonia species and contact the anthers while foraging. However, the bodies of these insects are too small to regularly contact the stigmas while foraging for pollen and/or nectar, despite their high density and repeated visitations of flowers in some Persoonia populations. Cross-pollination by Trigona may be confounded further by the presence of corbiculae and pollen pellets as described, above, in A. mellifera (Michener 1974).

On the other hand, while an increase in physical size ensures a native insect's access to the nectar chamber, encouraging passive contact with the stigma, it does not guarantee that the same insect will always transport loads of Persoonia pollen. Although Amegilla, Chalicodoma species, and some wasps are longer than Exoneura and Leioproctus (Cladocerapis) species by $3-4 \mathrm{~mm}$, they appear to be inferior pollen vectors. These larger native hymenopterans contact stigmas while depressing the tepals but they were not observed to forage actively for pollen on Persoonia anthers. Their pollen load analyses showed they acquire little pollen while collecting nectar.

Therefore, while tube length varies greatly between Persoonia species of eastern Australia there is little evidence of a correlation between the physical length of the floral tube and the body length or tongue length of its true pollinators. Based on measurements of the three to four, native taxa of common pollen vectors the differing lengths of floral tubes between Persoonia species does not appear to have encouraged the segregation of different pollinator species to different Persoonia species in eastern Australia. Since access to nectar is based on the physical strength and foraging behaviour of the bee a correlation between the actual length of the hinged tepals Persoonia species and the length of their pollinators' probosces should not be anticipated.

Perhaps both the sheer length and/or degree of constriction of the tepals around the nectar chamber helps to restrict the loss of nectar reserves to smaller thieves. Filiglossa and Trigona species have long mouthparts for their small size. Directional selection may have favoured increased tepal length where nectar thieves occur at higher densities. For example, the flower of Persoonia arborea has the longest floral tube and its exposed ovary forms a cap over the narrowed, nectar chamber. Persoonia arborea grows in an area where it is visited by swarms of Leioproctus (Filiglossa) davisi (K. Walker, personal communication). These bees don't contact the flower's stigma and are shown to be poor, pollen vectors in this study. In Persoonia pinifolia the long tepals appear tightly wrapped around the style above the pouched, nectar chamber. Trigona carbonaria is the most commonly collected and observed visitor on flowers of the $P$. pinifolia population in this study.

This is the first study to compare the pollen carrying capacity of male and female bees. While most males in the subgenus Cladocerapis fail to carry heavier loads than females, $85 \%$ of these males carry from 25 to $>100$ grains of Persoonia pollen although none forage actively for pollen. Cladocerapis males then are actually superior vectors of Persoonia pollen than nectar foraging females of Amegilla and Chalicodoma species. This also suggests that, at certain sites, Cladocerapis males are probably far more important 
as pollinators of Persoonia species than female, pollen-foraging, Halictidae (Lasioglossum and Nomia species) because collections suggested that the density of pollen laden, Cladocerapis males was appreciably higher than halictid females. Active pollen collection by some halictids was inferior to passive collection by some Cladocerapis males since only $40 \%$ of female Nomia bees carried significant loads of Persoonia pollen.

The evolution of Leioproctus species dependent on floral rewards produced by Persoonia flowers has resulted in two quite different foraging syndromes. Within subgenus Cladocerapis, larger body size, reduction of facial hairs, and an unusual mode of pollen collection by females contribute to mutual benefits for both the bees and the Persoonia flowers they pollinate.

In direct contrast, body size is reduced, mouthparts are much elongated or ornamented with long hairs and foraging behaviour encourages basal probing of the nectar chamber in subgenus Filiglossa. This form of floral parasitism does not obviously benefit the reproductive ecology of Persoonia and, as mentioned above, may have encouraged evolution of longer tepals, or style-clasping tepals, or tube-blocking ovaries. Two congeneric bees then occupy the same trophic levels but

Table 9. Identification of pollen grains of bees and wasps carrying Persoonia mixed with the pollen of at least one other species.

Insect Taxon

Pollen Taxa

$\begin{array}{lcccccccccc} & \text { AC } & \text { AS } & \text { BA } & \text { EP } & \text { LA } & \text { MY } & \text { PL } & \text { PE } & \text { UD } & \text { UM } \\ \text { Apis mellifera } & 0 & 1 & 0 & 0 & 0 & 13 & 0 & 13 & 3 & 0 \\ \text { Callomelitta sp. } & 0 & 0 & 0 & 0 & 0 & 0 & 1 & 0 & 1 & 0 \\ \text { Chalicodoma spp. } & 4 & 2 & 0 & 0 & 1 & 4 & 0 & 10 & 8 & 0 \\ \text { Exoneura spp. } & 2 & 5 & 0 & 0 & 1 & 13 & 0 & 18 & 7 & 0 \\ \text { Homalictus urbanus } & 1 & 1 & 0 & 0 & 0 & 1 & 0 & 1 & 0 & 0 \\ \text { Lchneumonid wasp } & 0 & 0 & 0 & 0 & 0 & 1 & 0 & 1 & 0 & 0 \\ \text { Lasioglossum brazieri } & 0 & 1 & 0 & 0 & 0 & 0 & 0 & 1 & 0 & 0 \\ \text { L. sp. (Parasphecodes) } & 0 & 0 & 0 & 0 & 0 & 1 & 0 & 1 & 1 & 0 \\ \text { Leioproctus (Cladocerapsis) spp. } & 2 & 0 & 0 & 0 & 0 & 4 & 0 & 5 & 2 & 0 \\ \text { L. bipectinatus } & 0 & 0 & 0 & 0 & 0 & 1 & 0 & 1 & 0 & 0 \\ \text { L. carinatifrons } & 1 & 0 & 1 & 0 & 0 & 3 & 0 & 4 & 1 & 0 \\ \text { L. (Filiglossa) spp. } & 0 & 0 & 0 & 0 & 0 & 1 & 0 & 3 & 2 & 1 \\ \text { L. incanescens } & 0 & 0 & 1 & 0 & 0 & 27 & 2 & 30 & 1 & 0 \\ \text { L. raymenti } & 0 & 0 & 0 & 0 & 0 & 2 & 0 & 6 & 6 & 0 \\ \text { L. speculiferus } & 0 & 0 & 0 & 0 & 0 & 28 & 7 & 41 & 13 & 0 \\ \text { Nomia spp. } & 0 & 0 & 1 & 1 & 1 & 1 & 0 & 2 & 1 & 0 \\ \text { Odyneurus sp. } & 0 & 0 & 0 & 0 & 0 & 1 & 0 & 1 & 1 & 0 \\ \text { Trigona carbonaria } & 0 & 0 & 0 & 0 & 0 & 0 & 0 & 4 & 4 & 0 \\ \text { Totals } & 10 & 3 & 1 & 3 & 101 & 10 & 142 & 51 & 1 \\ & & & & & & & & & \end{array}$

$\mathrm{AC}=$ Acacia, $\mathrm{AS}=$ Asteraceae $($ Brachycome, Hypochaeris), $\mathrm{BA}=$ Banksia $\mathrm{EP}=$ Epacridaceae $($ Epacris sp. and E. pulchella), LA = Unidentified Lamiaceae (Prostanthera type); MY = Myrtaceae (Eucalyptus,Leptospermum), $\mathrm{PE}=$ Persoonia spp.; PL = Platysace lanceolata (Apiaceae), UD = Unidentified dicots (triporate and tricolporate); UM = Unidentified monocot (Iridaceae type) 
may avoid direct contact with each other. This may reduce the immediate effects of direct competition for the same energy source because foraging for the same nectar occurs at opposite ends of the same flowers.

How interdependent, though, are Persoonia species, their true pollinators and their nectar/pollen thieves? Exoneura species have long been known to be polylectic foragers in Australia and we expected alien mixtures of pollens carried by Exoneura bees caught on Persoonia flowers based on the foraging record for this bee genus (Rayment 1935; Armstrong 1979; Bernhardt 1984, 1989). Some Exoneura species regularly visit both nectariferous taxa (Asteraceae, Myrtaceae, papilionoid legumes, Spyridium) and taxa that lack floral nectaries but produce copious pollen (Acacia, Dianella, Hibbertia) during the same foraging bout (Bernhardt 1989, 1995, and in progress).

However, pollen load analysis in this study also shows that neither Cladocerapis nor Filiglossa bees always forage exclusively on Persoonia. Despite unusual morphological and ethological modifications that might be associated with foraging on Persoonia flowers (Maynard 1995), members of the two subgenera of Leioproctus take nectar and pollen from other plants. We must presume that mixed loads of pollen found in the scopae of such bees will still be used to feed larvae.

Cladocerapis bees are dominant pollinators of Persoonia species at most study sites due, in part, to sheer numbers. Their mode of pollen collection is unlike any of the other prospective pollinators of Persoonia. However, there is still little direct evidence, at present, to indicate that Persoonia flowers and Cladocerapis bees are models of long-term co-adaptation. First, pollen load analyses of Cladocerapis bees indicate that Persoonia is not their exclusive source of pollen. Cladocerapis bees are facultative, not obligate, oligoleges (sensu Michener 1979) of Persoonia flowers.

Second, taxonomists separate Exoneura from Leioproctus by family and the mouthparts of the two genera differ greatly in length. That is why sugar analyses of nectar of two Persoonia species seem so contradictory. Sucrose-dominant nectars like those of the two Persoonia species analysed are most often associated with long-tongue bees (Baker and Baker 1989) like members of the Apidae (e.g. Apis mellifera) and Anthophoridae (e.g. Exoneura). That may explain, in part, why naturalised $A$. mellifera forages so often on Persoonia. If the nectar of Persoonia flowers were hexose-dominant or hexose-rich then exclusive pollination by short-tongue bees might be expected (Kenrick et al. 1987; Baker and Baker 1989). While eastern Persoonia species and Cladocerapis bees certainly show some co-adapted features their interrelationship is not mutually exclusive.

Of wider interest, note that the bees that forage preferentially on sympatric, coblooming Persoonia species at Hilltop and Nerriga showed little evidence of resource partitioning. In his work on bee foraging in mediterranean habitats in the western Hemisphere Moldenke (1976) concluded that resource partitioning by bees showed a positive correlation with floral diversity. That is, as floral diversity increases over time, bees will visit the flowers of fewer plant species. Bees then avoid interspecific competition for the same pollen and/or nectar resources.

Bernhardt (1989) did not find this correlation while studying the pollination ecology of Acacia species in south-eastern Australia. To the contrary, as floral diversity increased over the season, bees collected on Acacia species were more likely to carry the pollen of other co-blooming angiosperms. At the time, this was understood to be an exception to the rule, reflecting a narrow reward system since Acacia species in Australia lack floral nectaries. Since most bees that collect Acacia polyads are generalist foragers it was assumed that nectar from co-blooming taxa was essential to provide these bees with sufficient chemical energy to support continued foraging for pollen on nectarless Acacia. This should not have happened on Persoonia flowers at the Hilltop site. The flowers of each of the sympatric, Persoonia species sampled should have been dominated 
by only one Cladocerapis species if Moldenke's predictions extend beyond the Californian flora. Instead, collections indicated that there was no obvious domination of a Persoonia species by one of each of the three Cladocerapis species. Pollen load analyses indicated that some members of all three Cladocerapis species continued interspecific foraging on Persoonia at Hilltop. Perhaps resource partitioning by bees can occur only if floral diversity and density increases while bee diversity and density remains constant.

We may confirm then that the high frequency of F1 hybrids recorded between Persoonia species in eastern Australia is based on the general weakness of all prezygotic barriers associated with interspecific isolation. Persoonia species in eastern Australia are often sympatric and floral phenology shows a broad overlap. The mere presence of first generation hybrids indicates that some parent species are intercompatible. Different suites of floral characters in Persoonia such as floral tube length, anther colour and differing scents do not visibly discourage interspecific foraging by the four to five taxa of major pollinators.

At the Hilltop site the same three Leioproctus (Cladocerapis) species were collected on each of the three, co-blooming Persoonia species. At Nerriga, the most common pollinator, $L$. incanescens, was collected on co-blooming P. microphylla and P. mollis. When native pollinators fail to discriminate between the flowers of shrubs in the same genus recurrent hybridisation cannot be blamed exclusively on the naturalised A. mellifera.

When Persoonia species are sympatric and have overlapping flowering periods, up to $28 \%$ of their primary pollinators make interspecific foraging bouts. This helps to explain the high frequency of F1 hybrids in Persoonia in eastern Australia. In some other angiosperm genera (e.g. Iris, Phlox, Opuntia, Quercus) the comparative lack of interspecific isolation has encouraged introgression or microspeciation (see review in Futuyma 1986). The comparative lack of autoploidy and backcrossing between parents and first generation hybrids in Persoonia suggests that postzygotic barriers (eg. F1 sterility or poor survival rate) may be more important in the maintenance of interspecific isolation in this genus.

Under these circumstances the genus Persoonia in eastern Australia may represent a species flock (sensu Mayr 1963). This section of the genus would have radiated rapidly during the Tertiary (Weston 1981, Truswell 1990). With the retreat of rainforests and moist Nothofagus forests, Persoonia might have undergone rapid speciation within the expanding and fragmenting shrublands and eucalypt forests (Truswell 1990). Just as the diversification of the orchid genus, Thelymitra, is identified by the key innovation of fusion of the column wings above and behind the fertile anther (Burns-Balogh \& Bernhardt 1988; Bernhardt 1993), diversification within Persoonia may have depended, in part, on the evolution of basally hinged tepals forming a nectar chamber under the stalked ovary.

The Persoonioideae lack such derived reproductive features as the massive inflorescence, protostigma, biporate pollen grain, reinforced-wiry styles, zygomorphic nectary found elsewhere in the family. It is tempting to speculate that insectpollination is ancestral to the Proteaceae with vertebrate pollination secondarily derived. This recurrent trend in floral evolution has been proposed repeatedly for other families including the Polemoniaceae (Grant and Grant 1965), Fabaceae sens. lat. (Arroyo 1981) and the Orchidaceae (Dressler 1981).

Of course, this hypothesis must be treated with considerable caution. Persoonia pollination does not follow the patterns of generalist entomophily described, for example, in the relictual magnolioids and their allies. In these families pollination is achieved by the much broader exploitation of a wide range of insects in different Orders (Hymenoptera, Coleoptera, Lepidoptera, Thysanoptera, Diptera). These insects have small bodies and often lack forelegs modified to manipulate anthers (Barth 
1985; Bernhardt and Thien 1987; Thien et al. 1994). The Persoonia species of eastern Australia have a much more specialised system of pollination and recruit relatively few of the many genera of native bees as true pollinators. It is unlikely, then, that persoonia sens. strict. can be used as a specific model to predict ancestral modes of pollination in the Proteaceae.

\section{Acknowledgements}

Research was funded by two Fellowships to P. Bernhardt (1990-1992 and 1994) provided by the Royal Botanic Gardens and Domain Trust, Sydney. We would like to thank John Myers for drawing Figs 1, 2 and 6. Particular thanks are expressed to Ms Natasha Baczocha, Mr T. Hawkeswood, Ms Denise Day, Ms Catriona McPhee and Dr K. Walker who assisted in the collection and preparation of insect specimens and helped to record data over three seasons. Drs B.G. Briggs, S.L. Krauss, G.V. Maynard and Peter Wilson provided helpful comments on the manuscript; we remain responsible for residual deficiencies. We gratefully acknowledge the advice, encouragement and pioneering research of Dr L.A.S. Johnson on the Proteaceae and on Persoonia in particular.

\section{References}

Armstrong, J.A. (1979) Biotic pollination mechanisms in the Australian flora - a review. New Zealand J. Bot. 17: 467-508.

Arroyo, M.T.K. (1981) Breeding systems and pollination in Leguminoseae. Pp. 723-769 in R.M. Polhill and P.H. Raven (eds.), Advances in Legume Systematics, Part 2. (Royal Botanic Gardens, Kew: London).

Baker, H.G. and Baker, I. (1989) The predictive value of nectar chemistry to the recognition of pollinator types. Israel J. Bot. 39: 157-166.

Barth, F.G. (1985) Insects and Flowers: the Biology of a Partnership (Princeton Univ. Press: Princeton).

Bernhardt, P. (1984) The pollination biology of Hibbertia stricta (Dilleniaceae). Pl. Syst. Evol. 147: 266-377.

Bernhardt, P. (1988) Thelymitra. Pp. 146-154 in G.J. Harden (ed.). Flora of New South Wales, vol 4 (New South Wales Univ. Press: Kensington).

Bernhardt, P. (1989) The floral ecology of Australian Acacia. Pp. 127-155 in C.H. Stirton and J.L. Zarruchi (eds.) Advances in Legume Biology (Missouri Botanical Garden: St Louis).

Bernhardt, P. (1995) The floral ecology of Dianella caerulea var. assera (Phormiaceae). Cunninghamia 4: 9-20.

Bernhardt, P. and Thien, L.B. (1987) Self-isolation and insect pollination in the primitive angiosperms: new evaluations of older hypotheses. Pl. Syst. Evol. 156: 159-176.

Buchmann, S.L., Jones, C.E. and Colin, L.J. (1978) Vibratile pollination of Solanum douglasii and S. xanthi (Solanaceae) in southern California. Wasmann J. Biol. 35: 1-25.

Burns-Balogh, P. and Bernhardt, P. 1988. Floral evolution and phylogeny in the tribe Thelymitreae (Orchidaceae: Neottioideae). Pl. Syst. Evol. 156: 19-47.

Carolin, R.C. (1961) Pollination of the Proteaceae. Aust. Mus. Mag. Sept. 1961: 371-374.

Collins. B.G. and Rebelo, T. (1987) Pollination biology of the Proteaceae in Australia and southern Africa. Aust J. Ecol. 12: 387-421.

Dressler, R. (1981) The Orchids; Natural History and Classification (Harvard Univ. Press: Cambridge, Mass.).

Faegri, K. and van der Pijl, L. (1979) The Principles of Pollination Ecology, 3rd edn. (Pergamon Press: Oxford).

Feuer, S. 1986. Pollen morphology and evolution in the Persoonioideae, Sphalmioideae and Carnarvonioideae (Proteaceae). Pollen et Spores 28: 123-156.

Futuyma, D.J. (1986) Evolutionary Biology, 2nd edn. (Sinauer Associates: Sunderland, Mass.).

Grant, V. and Grant, K.A. (1965) Flower Pollination in the Phlox Family (Columbia Univ. Press: New York). 
Hopper, S.D. and Burbidge, A.A. (1982) Relative importance of birds and mammals as pollinators of a banksia and a eucalypt. Pp. 67-75 in J.A. Armstrong, J.M. Powell, and A.J. Richards (eds.), Pollination and Evolution (Royal Botanic Gardens: Sydney).

Hopper, S.D. and Burbidge, A.A. (1986) Speciation of bird-pollinated plants in south-western Australia. Pp. 20-31 in H. Ford and D.C. Paton (eds.) The Dynamic Partnership: Birds and Plants in Southern Australia (Govt. Printer: Adelaide).

Johnson, L.A.S. and Briggs, B.G. (1975) On the Proteaceae - the evolution and classification of a southern family. Bot. J. Linn. Soc. 70: 83-182.

Kearns, C.A. and Inouye, D.W. 1993. Techniques for Pollination Biologists (Univ. Press Colorado: Niwot).

Kenrick, J., Bernhardt, P., Marginson, R., Beresford, G., Knox, R.B., Baker, I. and Baker, H.G. (1987) Pollination-related characteristics in the mimosoid legume Acacia terminalis (Leguminoseae). Pl. Syst. Evol. 157: 49-62.

Krauss, S.L. (1994a) Preferential outcrossing in the complex species Persoonia mollis R. Br. (Proteaceae). Oecologia 97: 256-264.

Krauss, S.L. (1994b) Restricted gene flow within the morphologically complex species Persoonia mollis (Proteaceae): contrasting evidence from the mating system and pollen dispersal. Heredity 73: $142-154$.

Law, B.S. (1994) Banksia nectar and pollen: dietary items affecting the abundance of the common blossom bat, Syconycteris australis, in southeastern Australia. Austral. J. Ecol. 19: 425-434.

Maynard, G.V. (1992) Revision of Leioproctus (Cladocerapis) Cockerell (Hymenoptera: Colletidae). I. Aust. Ent. Soc. 31: 1-11.

Maynard, G.V. (1994) Revision of Leioproctus (Filiglossa) Rayment (Hymenoptera: Colletidae). J. Aust. Ent. Soc. 33: 299-304.

Maynard, G.V. (1995) Pollinators of Australian Proteaceae. Flora of Australia 16: 30-36.

Mayr, E. (1963) Animal Species and Evolution (Harvard Univ. Press: Cambridge, Mass.).

Michener, C.D. (1974) The Social Behavior of the Bees (Belknap Press: Cambridge, Mass.).

Michener, C.D. and Houston, T.F. (1991) Superfamily Apoidea. Pp. 993-1000 in Insects of Australia 2nd edn. (Melbourne Univ. Press: Carlton).

Michener, C.D. (1979) Biogeography of the bees. Ann. Missouri Bot. Gard. 71: 17-29.

Moldenke, A.R. (1976) Evolutionary history and diversity of the bee faunas of Chile and Pacific North America. Wasmann J. Biol. 34: 147-178.

Paton, D.C. (1985) Evolution of bird pollination in Australia. Pp. 32-41, in H. Ford and D.C. Paton (eds.) The Dynamic Partnership: Birds and Plants in Southern Australia (Govt. Printer: Adelaide).

Pyke, G.H. and Waser, N.M. (1981) The production of dilute nectars by hummingbird and honeyeater flowers. Biotropica 13: 260-270.

Rayment, T. (1935) A Cluster of Bees (Endeavour Press: Sydney).

Rayment, T. (1950) New bees and wasps - part XV. Victorian Naturalist 67: 101-111.

Rayment, T. (1959) A new genus of bees in the family Colletidae. Australian Zoologist 12: 324-329.

Richards, A.J. (1986) Plant Breeding Systems (Allen and Unwin: London).

Sussman, R.W. and Raven, P.H. (1978) Pollination by lemurs and marsupials: an archaic coevolutionary system. Science 200: 731-734.

Thien, L.B., Ellgaard, E.G., Devall, M.S., Ellgaard, S.E. and Ramp, P.F. (1994) Population structure and reproductive biology of Saururus cernuus L. (Saururaceae). Pl. Spec. Biol. 9: 47-55.

Trusswell, E.M. (1990) Australian Rainforests: The 100 million year record. Pp. 7-22, in Webb, L.J. and Kikkawa, J. (eds.) Australian Tropical Rainforests: Science - Values - Meaning (CSIRO Publications: East Melbourne).

Turner, V. (1982) Marsupials as pollinators in Australia. Pp. 55-66, in J.A. Armstrong, J.M. Powell and A.J. Richards (eds.), Pollination and Evolution (Royal Botanic Gardens: Sydney).

Weston, P.H. (1983) The systematics and biogeography of the Persooniinae (Proteaceae) (unpublished Ph.D. thesis: Univ. Sydney).

Weston, P.H. (1991) Persoonia. Pp. 3-19 in G.J. Harden (ed.), Flora of New South Wales, vol. 2 (New South Wales Univ. Press: Kensington).

Weston, P.H. (1994) The Western Australian species of subtribe Persooniinae (Proteaceae: Persoonioideae: Persoonieae). Telopea 6: 51-165.

Weston, P.H. and Johnson, L.A.S. (1991) Taxonomic changes in Persoonia (Proteaceae) in New South Wales. Telopea 4: 269-306. 


\section{Appendix - Study Sites}

Persoonia acerosa (PHW 1954), P. levis (PHW 1956), Persoonia acerosa $\times$ P. levis (PHW 1955). Bells Line of Road, $4.3 \mathrm{~km} \mathrm{~W}$ of turn-off to Mt Tomah Botanic Garden, 33⒊'00"S $150^{\circ} 23^{\prime} 41^{\prime \prime E}$; dry sclerophyll forest dominated by Eucalyptus piperita and E. sclerophylla; understorey with Gahnia, Platysace, Acacia terminalis, A. oblongifolia, Petrophile pulchella, Epacris, Telopea speciosissima, Leptospermum trinervium, Polyscias sambucifolia, Pimelea, Ozothamnus.

Persoonia arborea (K. Walker s.n.). About 9-15 km W of Mt Baw Baw, 3750'S 146²17'E, alt. $930 \mathrm{~m}$; wet sclerophyll forest, shrubby understorey and subcanopy of $P$. arborea.

Persoonia asperula (PHW 1763), P. chamaepeuce (PHW 1762). One km S of Pikes Saddle, $36^{\circ} 59^{\prime} 40^{\prime \prime} \mathrm{S} 149^{\circ} 34^{\prime} 00^{\prime \prime E}$, alt. $1280 \mathrm{~m}$; dry sclerophyll woodland dominated by Eucalyptus pauciflora; understorey dominated by Oxylobium ellipticum, Persoonia silvatica and the two other Persoonia species.

Persoonia chamaepitys (PHW 1738), P. laurina subsp. laurina (PHW 1274), P. levis, P. mollis subsp. mollis (PHW 103), P. myrtilloides subsp. myrtilloides (PHW 1739).

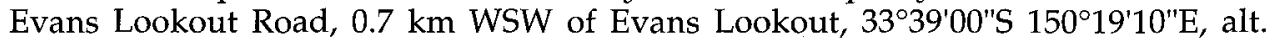
$975 \mathrm{~m}$; dry sclerophyll forest dominated by Eucalyptus sclerophylla, E. sieberi; shrubby understorey with six Persoonia spp., Acacia obtusifolia, Lambertia formosa, Leptospermum trinervium, Telopea speciosissima.

Persoonia glaucescens (PHW 1774), P. lanceolata (PHW 1776), P. mollis subsp. nectens (PHW 1775). Approximately $0.3 \mathrm{~km} \mathrm{~N}$ of Banksia Street, on West Road Fire Trail, Hill Top, $34^{\circ} 20^{\prime} 30^{\prime \prime S} 150^{\circ} 29^{\prime} 00^{\prime \prime E}$, Alt. $560 \mathrm{~m}$; dry sclerophyll forest dominated by Corymbia gummifera, Eucalyptus piperita, E. sclerophylla, E. sparsifolia, E. sieberi, E. punctata; shrubby understorey with three Persoonia species listed above, P. laurina subsp. intermedia, Banksia spinulosa, Hakea sericea, Acacia obtusifolia, A. terminalis, Daviesia corymbosa, Lambertia formosa, Eriostemon australasius.

Persoonia isophylla (PHW 1781). Greta Road, $1.0 \mathrm{~km}$ W of junction with Bumble Hill

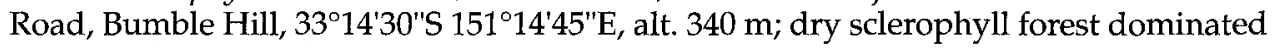
by Corymbia gummifera, Eucalyptus haemastoma, E. oblonga; shrubby understorey with P. isophylla, P. levis, Angophora hispida, Lambertia formosa, Leptospermum trinervium, Petrophile pulchella.

Persoonia isophylla (PHW 1783). $2.8 \mathrm{~km} \mathrm{~S}$ of Peats Ridge, 3320'30"S 151 ${ }^{\circ} 13^{\prime} 45^{\prime \prime} \mathrm{E}$. alt. $280 \mathrm{~m}$; disturbed dry sclerophyll forest dominated by Corymbia gummifera, Eucalyptus haemastoma, E. oblonga, shrubby understorey with $P$. isophylla, P. levis, P. lanceolata, Lambertia formosa, Hakea gibbosa, H. sericea, Leptospermum trinervium, Epacris pulchella, Petrophile pulchella, Banksia serrata, Telopea speciosissima.

Persoonia laurina subsp. laurina (PHW 1730), P. nutans (PHW 1731). Penrith Road,

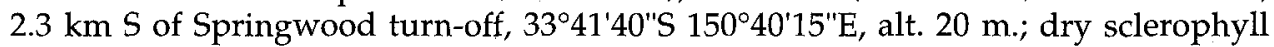
forest dominated by Angophora bakeri, Eucalyptus sclerophylla, with a shrubby understorey of $P$. nutans, P. laurina, Banksia serrata, Ricinocarpus pinifolius, Leptospermum trinervium, Hibbertia diffusa.

Persoonia microphylla (PHW 1768), P, mollis subsp. livens (PHW 1769), P. microphylla $\times$ $P$. mollis subsp. livens (PHW 1424). Nerriga-Goulburn road, $0.7 \mathrm{~km}$ ESE of NerrigaBraidwood road, $35^{\circ} 08^{\prime} 40^{\prime \prime} \mathrm{S} 150^{\circ} 03^{\prime} 30^{\prime \prime} \mathrm{E}$, alt. $600 \mathrm{~m}$; open, disturbed roadside reserve through pasture with remnant dry sclerophyll forest with two Persoonia spp. and their hybrids, Eucalyptus dives, E. mannifera, Banksia marginata, Acacia decurrens, A. rubida, Allocasuarina littoralis. 
Persoonia mollis subsp. ledifolia (PHW 1778), P. oxycoccoides (PHW 1777). $1.0 \mathrm{~km}$ ENE of Carrington Falls, Budderoo National Park, 34 37'00"S 150 $39^{\prime} 30^{\prime \prime} \mathrm{E}$, alt. $570 \mathrm{~m}$; dry sclerophyll woodland dominated by Eucalyptus sieberi, E. piperita, shrubby, sedgy understorey with two Persoonia species listed above, P. laurina subsp. leiogyna, $P$. levis, Banksia paludosa, unidentified Epacridaceae.

Persoonia mollis subsp. leptophylla (PHW 1771). Tianjara Falls, 3506'40"S 150¹9'50"E, alt. $500 \mathrm{~m}$; dry sclerophyll woodland with Corymbia gummifera, Eucalyptus consideniana, dense shrubby understorey with P. mollis, Banksia paludosa, Acacia obtusifolia, Allocasuarina littoralis, Lambertia formosa, Lomatia myricoides, Leptospermum rotundifolium, Kunzea ambigua.

Persoonia mollis subsp. livens (P. Kodela 4076). $3 \mathrm{~km} \mathrm{~S}$ of Boro River crossing on Mayfield to Braidwood road, $23^{\circ} 14^{\prime} \mathrm{S} 149^{\circ} 48^{\prime} \mathrm{E}$. Gently undulating plain, on chalky sand over Ordovician metasediments. Open eucalypt woodland with a sparse understorey with Eucalyptus rossii, E. mannifera, Leptospermum trinervium, Banksia spinulosa, Restio fimbriatus.

Persoonia oblongata (PHW 1748). Richmond-Springwood road, $2.0 \mathrm{~km} \mathrm{E} \mathrm{of} \mathrm{turn-off} \mathrm{to}$

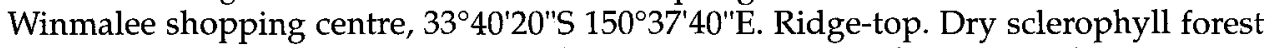
dominated by Eucalyptus sparsifolia, Corymbia gummifera, Angophora costata, Allocasuarina littoralis; shrubby understorey with Persoonia pinifolia, P. levis, P. linearis, $P$. oblongata. Fine-grained sandstone or coarse-grained shale?

Persoonia pinifolia (R.G. Coveny 15180). Gungulla Flat, SE of Waterfall, Royal National Park, 34 $09^{\prime} 00^{\prime \prime S} 151^{\circ} 00^{\prime} 30^{\prime \prime E}$ alt. $150 \mathrm{~m}$; dry sclerophyll forest dominated by Eucalyptus sieberi, Angophora costata and understorey of P. pinifolia (RGC 15180).

Persoonia silvatica (PHW 1761). $2.0 \mathrm{~km} \mathrm{~S}$ of Pikes Saddle, 3600'10"S 149³4'00"E, alt. $1280 \mathrm{~m}$; dry sclerophyll forest dominated by Eucalyptus fraxinoides, open understorey of $P$. silvatica with Platysace lanceolata, Lomandra longifolia, Dianella, Stylidium graminifolium, Acacia dealbata.

P. subvelutina (PHW 1764). Island Bend-Guthega Road, $1.5 \mathrm{~km}$ WSW of Island Bend rest area, $36^{\circ} 20^{\prime} 00^{\prime \prime S} 148^{\circ} 27^{\prime} 30^{\prime \prime} \mathrm{E}$, alt. $1280 \mathrm{~m}$; dry sclerophyll forest dominated by Eucalyptus pauciflora; shrubby and grassy understorey with P. subvelutina, Hakea microcarpa, Daviesia ulicifolia, Epacris spp., Leptospermum spp. and Arthropodium milleflorum.

P. virgata (no voucher). Hastings Point, $28^{\circ} 22^{\prime} \mathrm{S} 153^{\circ} 35^{\prime} \mathrm{E}$. 